\title{
Forest and Rangeland Soil Biodiversity
}

\author{
Stephanie A. Yarwood, Elizabeth M. Bach, Matt Busse, \\ Jane E. Smith, Mac A. Callaham Jr, Chih-Han Chang, \\ Taniya Roy Chowdhury, and Steven D. Warren
}

\section{Introduction}

Regardless of how soil is defined, soils are the most diverse of all ecosystems. It is estimated that $25-30 \%$ of all species on Earth live in soils for all or part of their lives (Decaëns et al. 2006). A single gram of soil is estimated to contain $1 \times 10^{9}$ microorganisms, roughly the same population size as the number of humans in Africa (Microbiology by Numbers 2011). That same gram of soil likely contains 4000 species. They are only one part of a larger food web, however, that includes roundworms (phylum Nematoda), springtails (order Collembola), and other fauna (Fig. 5.1). The soil fauna has equally astounding numbers (e.g., 40,000 springtails in $1 \mathrm{~m}^{2}$ ). Soil organisms, ranging from microbes to moles (family Talpidae), promote crop growth and livestock production (Barrios 2007; Kibblewhite et al. 2008), produce antibiotics (Wall et al. 2015), control nutrient loads in surface soils and groundwater (De Vries et al. 2011), and regulate greenhouse gas emissions (Singh et al. 2010).

Understanding the processes governing soil community size and composition and the functional implications of biodiversity is challenging. Many microorganisms and soil

S. A. Yarwood $(\square)$

Department of Environmental Science and Technology, University of Maryland, College Park, MD, USA

e-mail: syarwood@umd.edu

E. M. Bach

Global Soil Biodiversity Initiative, School of Environmental

Sustainability, Colorado State University, Fort Collins, CO, USA

M. Busse

U.S. Department of Agriculture, Forest Service, Pacific Southwest

Research Station, Davis, CA, USA

J. E. Smith

Forestry Sciences Laboratory, U.S. Department of Agriculture,

Forest Service, Pacific Northwest Research Station,

Corvallis, OR, USA animals utilize the same carbon (C) sources and mineralize at least a portion of that $\mathrm{C}$ to carbon dioxide $\left(\mathrm{CO}_{2}\right)$, but within any soil ecosystem, specialized organisms break down lignin, transform nitrogen $(\mathrm{N})$-containing molecules, and produce methane $\left(\mathrm{CH}_{4}\right)$. Few studies have systematically tested the role of biodiversity in maintaining both general and specialized functions, however. One study reported a loss of $\mathrm{N}$ cycling functions when microbial biomass was experimentally decreased using heat (Philippot et al. 2013b), but less drastic changes may also result in functional shifts undetectable with some of our current measurement methods, such as soil enzyme assays (Burns et al. 2013) or gas fluxes. Disturbance, development, and climate change may impact the functional capacity of forest and rangeland soils, but currently we have little information on the resistance and resilience of soil communities under these scenarios (Allison and Martiny 2008; Coyle et al. 2017) (Box 5.1).

Several studies have reported changes in soil biodiversity following disturbance. For example, bacterial diversity has been observed to increase in intermediate-aged soils created by glacial retreat (Sigler and Zeyer 2004) and land uplift (Yarwood and Högberg 2017), and mature soils typi-

M. A. Callaham Jr

U.S. Department of Agriculture, Forest Service, Southern Research Station, Center for Forest Disturbance, Athens, GA, USA

C.-H. Chang

Department of Environmental Science and Technology, University of Maryland, College Park, MD, USA

Department of Earth and Planetary Sciences, Johns Hopkins University, Baltimore, MD, USA

T. R. Chowdhury

Earth and Biological Sciences Division, Pacific Northwest National Laboratory, Richland, WA, USA

S. D. Warren

U.S. Department of Agriculture, Forest Service, Rocky Mountain Research Station, Provo, UT, USA 
Fig. 5.1 Soil organisms are linked together in a multitrophic food web. (Illustration by S. Yarwood, University of Maryland)

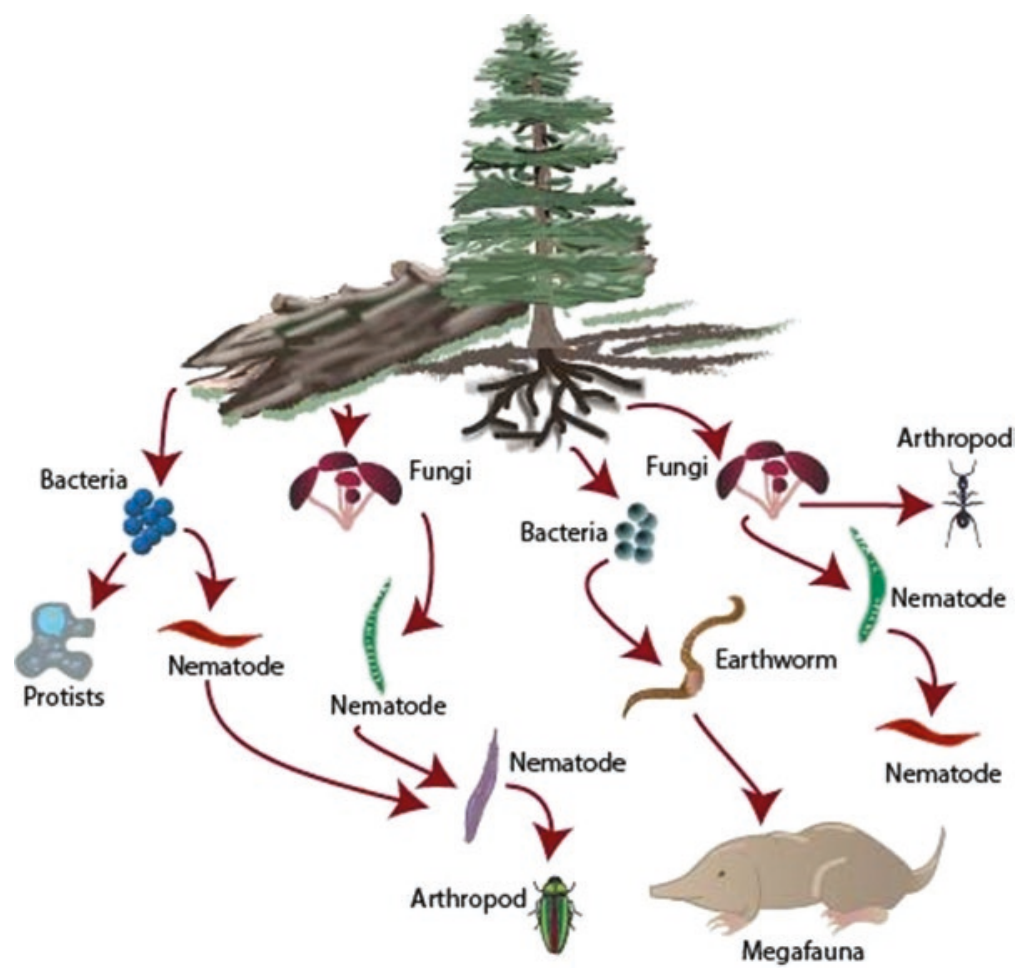

\section{Box 5.1 Resistance and Resilience}

Predicting how the community will react to disturbance requires information on both the resistance and resilience of the community. Resistance refers to the level of disturbance that a community can withstand before it is altered by the disturbance. In this case, predisturbance and postdisturbance measurements along a gradient, such as a fire intensity gradient, can be used to develop the metric (Cowan et al. 2016). A number of studies have been conducted on soil resistance (reviewed in Griffiths and Philippot 2013). Measuring resilience, however, is more complex. Resilience is defined as the rate at which a community returns to its original state following disturbance (Allison and Martiny 2008). Whereas resistance can be measured between two time points, resilience requires monitoring beyond the disturbance event for an often-unspecified timeframe. A disturbance may also lead to a new stable state that may even be functionally similar to the predisturbance condition, but this too is difficult to determine (Shade et al. 2012).

The large amount of functional redundancy (high biodiversity) of soils is thought to contribute to both resistance and resilience, but there are a number of studies that have observed sensitivity of the soil community to disturbance (Shade et al. 2012). Whether community changes lead to a change in function is largely unknown, but one model suggests that understanding a loss of biodiversity requires not only understanding the functions of the ecosystem under the environmental conditions that existed at the time of disturbance but also understanding how the community functions under different environmental conditions (Fetzer et al. 2015). In other words, a loss of biodiversity may not have immediate impacts on function, but changes may alter the functional capacity of the soil and affect the response when environmental conditions change.

cally contain more soil fauna, a phenomenon explained by the intermediate disturbance hypothesis (Connell 1978; Huston 2014). Soil detritivores also follow a successional pattern as plant litter decomposes, and such fine-scale temporal succession likely contributes to the high diversity found in soils (Bastow 2012). Both conditions highlight the importance of site legacy and temporal change on determining species richness. This begs the question: How do we interpret the majority of studies that have only examined the soil biota at a single time point?

To add another level of complexity, methods used to examine the soil community have changed, and new methods have been adopted for several decades. Following a long history of culture-based and microscopic approaches, the use of biomarkers such as lipids and nucleic acids has now become commonplace. The use of high-throughput sequencing technology 
to sufficiently capture soil biodiversity has only existed for the last decade, however, and easily accessible computational tools to analyze these data are still being developed. Trying to reconcile observations made using different methodologies continues to be challenging but will hopefully become easier as the soil ecology community pushes for increased consistency through the Earth Microbiome Project, the Global Litter Invertebrate Decomposition Experiment (GLIDE) (Wall et al. 2008), and other initiatives.

Many emerging studies of soil biodiversity, particularly for microorganisms and microfauna, target DNA (deoxyribonucleic acid) to capture the full community. However, this approach can also be problematic because of dormancy. At any time, $25-50 \%$ of all detected cells in soils may be dormant (Lennon and Jones 2011), and DNA includes both active and inactive communities. Aside from dormancy, there is also a growing recognition that soils contain extracellular relic DNA (Carini et al. 2016; Dlott et al. 2015). Relic DNA complicates our understanding of the current communities because it simultaneously reflects current conditions as well as legacy conditions. In the case of relic DNA, treating soils with DNAse before extractions may eliminate this inactive pool (Lennon et al. 2017), but this is not commonly done. It should also be noted that relic DNA can be used to study soil animals such as earthworms (Ficetola et al. 2015). It is likely that relic DNA and inactive cells have hampered efforts to connect the biological community to targeted functions. At the end of the chapter, we will discuss other emerging methods that may provide better insights into structure-function relationships.

Before discussing new methods, this chapter will introduce the various groups that compose the soil community, with emphasis on the known trends for each group of organisms in the forest and rangeland soils of the United States. These patterns will be discussed while acknowledging this caveat: All methods used have limitations and underlying assumptions that might not be met, and it is difficult to compare between studies that use different methods. After introducing the groups, we consider properties of the soil habitat that impact soil organisms, such as soil texture and plant communities. We will also discuss the likely impact that periodic disturbances (e.g., from fire or invasive species) and long-term climate changes have on soil biology. Finally, we will consider the future of forest and rangeland soil biology, highlighting emerging methods and long-term studies that promise to deepen our knowledge of soil biodiversity.

\section{Major Groups of Soil Organisms}

\section{Viruses}

Viral particles vary greatly in abundance across ecosystems; only a few hundred viruses were counted in hot desert soils, but forests and wetlands can contain $10^{9}$ viruses per gram
Table 5.1 Estimated diversity and abundance of soil organisms. These estimates should be considered preliminary, as most soil species have not been described

\begin{tabular}{|c|c|c|}
\hline Taxon & $\begin{array}{l}\text { Diversity per amount } \\
\text { of soil or area }\end{array}$ & $\begin{array}{l}\text { Abundance } \\
\text { (estimated) }\end{array}$ \\
\hline \multirow[t]{2}{*}{ Prokaryotes } & $100-9000$ & \multirow[t]{2}{*}{$4-20 \times 10^{9} \mathrm{~cm}^{-3}$} \\
\hline & $\begin{array}{l}\text { Genome } \\
\text { equivalents } \mathrm{cm}^{-3}\end{array}$ & \\
\hline \multirow[t]{2}{*}{ Fungi } & $200-235$ & \multirow[t]{2}{*}{$100 \mathrm{mg}^{-1}$} \\
\hline & $\begin{array}{l}\text { Operational } \\
\text { taxonomic units } \mathrm{g}^{-1}\end{array}$ & \\
\hline $\begin{array}{l}\text { Arbuscular mycorrhizal } \\
\text { fungi AMF (species) }\end{array}$ & $10-20 \mathrm{~m}^{-2}$ & $81-111 \mathrm{~m} \mathrm{~cm}^{-3}$ \\
\hline Protists & $\begin{array}{l}600-4800 \\
\text { sequences } g^{-1}\end{array}$ & $10^{4}-10^{7} \mathrm{~m}^{-2}$ \\
\hline Nematodes (genera) & $10-100 \mathrm{~m}^{-2}$ & $2-90 \times 10^{5} \mathrm{~m}^{-2}$ \\
\hline Enchytraeids & $1-15 \mathrm{ha}^{-1}$ & $\begin{array}{l}12,000- \\
311,000 \mathrm{~m}^{-2}\end{array}$ \\
\hline Collembola & $20 \mathrm{~m}^{-2}$ & $1-5 \times 10^{4} \mathrm{~m}^{-2}$ \\
\hline Mites (Orbatida) & $100-150 \mathrm{~m}^{-2}$ & $1-10 \times 10^{4} \mathrm{~m}^{-2}$ \\
\hline Isopoda & $10-100 \mathrm{~m}^{-2}$ & $10 \mathrm{~m}^{-2}$ \\
\hline Diplopoda & $10-2500 \mathrm{~m}^{-2}$ & $110 \mathrm{~m}^{-2}$ \\
\hline $\begin{array}{l}\text { Earthworms } \\
\text { (Oligochaeta) }\end{array}$ & $10-15 \mathrm{ha}^{-1}$ & $300 \mathrm{~m}^{-2}$ \\
\hline
\end{tabular}

Modified from Bardgett and van der Putten (2014), which includes additional references

dry weight (Kimura et al. 2008). Current knowledge of soil viruses is scarce, with only a handful of studies enumerating and characterizing them. Most of the literature describes soil viruses as bacteriophages, in part because bacteria are numerous in soils and because bacteriophages have been the target of most studies. Currently there are only about 2000 described soil viruses, a number too low to generate confidence in any prediction of diversity (Williamson et al. 2017). In aquatic systems, $10-50 \%$ of bacterial cell lysis is due to viruses, but their impact on bacteria and other soil populations is uncertain and needs more study (Williamson et al. 2017).

\section{Bacteria and Archaea}

Prokaryotes are the most abundant cellular organisms in soil and represent much of the DNA diversity on Earth (Table 5.1). Bacteria substantially outnumber archaea in terrestrial ecosystems, including forest soils, where archaea only account for $2 \%$ of the community (Bates et al. 2011). In both forests and grasslands, the dominant archaeal groups match putatively identified ammonia oxidizers (Bates et al. 2011), suggesting that their contribution to soil function may be narrowly defined. In contrast, bacteria include a wide range of functional groups: chemoheterotrophs, chemoautotrophs, and photosynthetic cyanobacteria (Fig. 5.2f). Particularly in arid rangelands, cyanobacteria are important in biological soil crusts (Briske 2017) (Box 

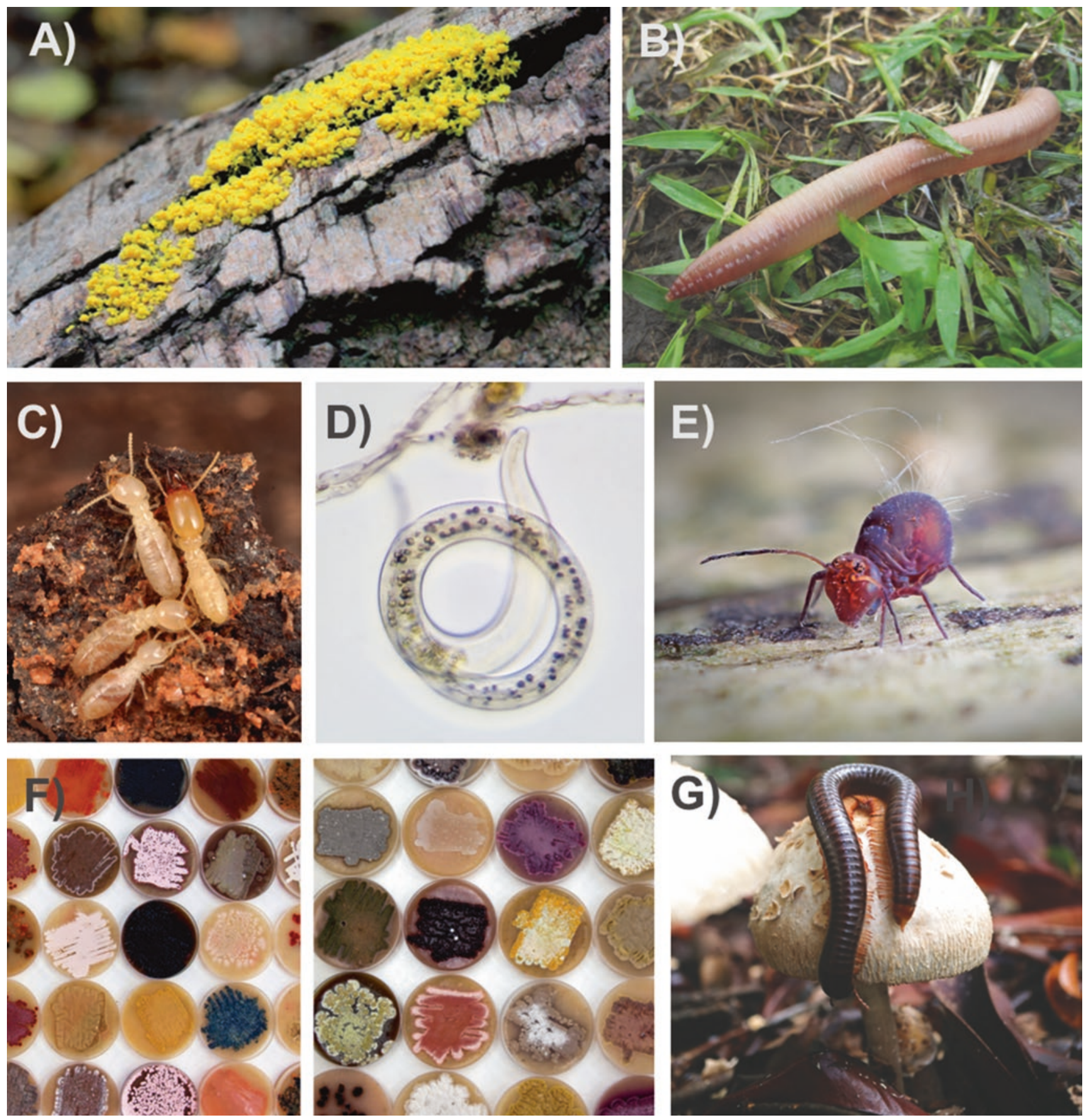

Fig. 5.2 Soil is home to more than $25 \%$ of the Earth's total biodiversity, including (a) slime molds (protists), (b) earthworms (Oligochaeta), (c) termites (Blattodea), (d) nematodes (Nematoda), (e) springtails (Collembola, Dicyrtoma fusca var. rubrocula), (f) bacteria, and (g) millipedes (Myriapoda) and mushrooms (fungi, genus Chlorophyllum).
(Photo Credits: (a) Creative Commons, Stu's Images; (b) Creative Commons slappytheseal; (c) M. Bertone; (d) D. Robson; (e) V. Gutekunst; (f) P. Turconi/Fondazione, Istituto Insubrico di Ricerca per la Vita; and (g) A. Harrington. All images used with permission)
5.2, Box figs. 5.1 and 5.2). Although major bacterial phyla such as Acidobacteria, Proteobacteria, and Verrucomicrobia are widely distributed in soils, there are also numerous candidate phyla with no cultured representatives (Youssef et al. 2015) and unknown function. Many studies have focused on comparing compositional differences among soil types. In the case of both archaea and bacteria, soil $\mathrm{pH}$ has been found to correlate to community composition across different types of ecosystems (Fierer et al. 2009). Although soil characteristics such as $\mathrm{pH}$, mineralogy, and texture appear 


\section{Box 5.2 Biological Soil Crusts}

Biological soil crusts develop where various combinations of diminutive bacteria, cyanobacteria, algae, nonlichenized fungi, lichens, bryophytes, and similar microorganisms occupy the surface and the upper few millimeters of the soil (Box Figs. 5.1 and 5.2). Historically, they have been called cryptobiotic, cryptogamic, microbiotic, microfloral, microphytic, or organogenic crusts. Biological soil crusts and the organisms that are part of the crust can be present individually or as consortia in a wide range of ecological, successional, and climatic conditions when and where disturbance or aridity, or both, has limited vascular plant cover and resulted in opportunities for colonization. However, they are most prevalent in arid and semiarid ecosystems where vascular plant cover and diversity are characteristically low, leaving large areas available for colonization by some combination of the organismal groups previously mentioned.

Crust organisms are distributed and dispersed globally in the atmosphere, and they are precipitated wherever and whenever climatic and atmospheric conditions allow (Warren et al. 2017). They are found in all ecosystems but are less represented in dense forests, grasslands, glaciers, and icecaps, where they seldom contact the mineral soil. The ecological roles of biological soil crusts are many and varied and include nutrient cycling, hydrology, and soil stabilization (Belnap and Lange 2001; Warren 1995; Weber et al. 2016). Soil crusts also serve as an essential food source for protozoans, nematodes, tardigrades, rotifers, mites, Collembola, and even larger arthropods and mollusks (Weber et al. 2016). Given the thousands of species involved and their variety, abundance, diversity, and ecological roles, biological soil crust organisms play

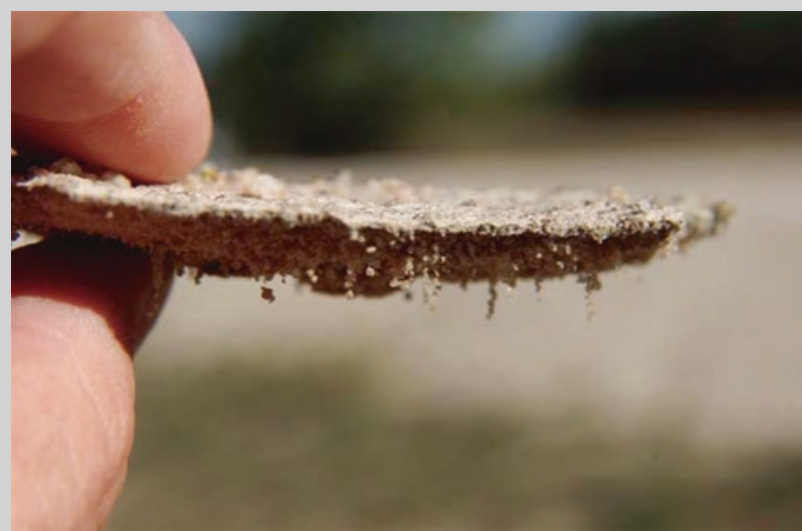

Box Fig. 5.1 Piece of soil crust with cyanobacteria dangling underneath. (Photo credit: Steve Warren, USDA Forest Service.)

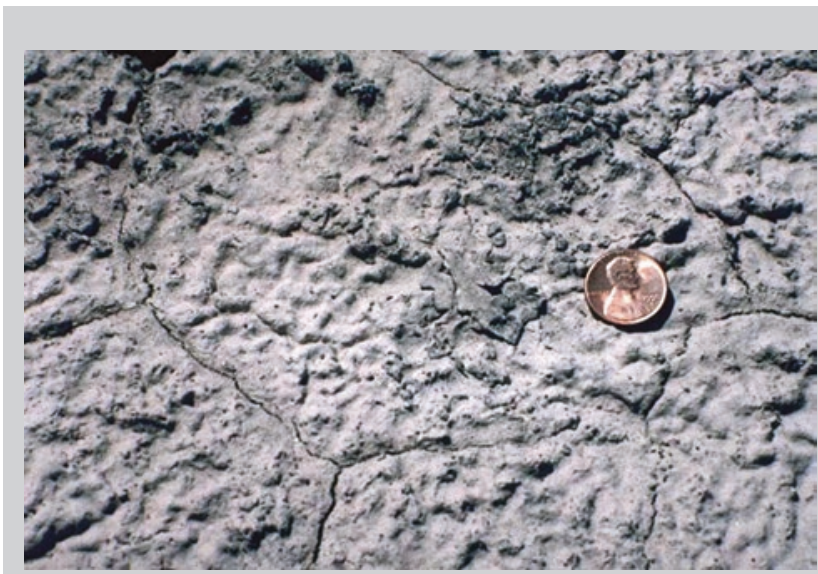

Box Fig. 5.2 Surface of a cyanobacterial crust in a fine-textured soil. (Photo credit: Steve Warren, USDA Forest Service.)

an essential role in the soil biodiversity of rangelands. Biological soil crusts and their ecological functions can be disturbed by a variety of factors, including livestock trampling (Warren and Eldridge 2001), off-road vehicles (Wilshire 1983), and fire (Johansen 2001), all of which are common on rangelands.

to be most important in influencing bacterial composition, shifts in species composition of vegetation communities have been correlated with shifts in microbial communities in some forest soil comparisons (Urbanová et al. 2015; Uroz et al. 2016).

\section{Fungi}

Across all soil types, fungi include both unicellular yeasts belonging to several taxonomic groups and filamentous species, the largest of which span $9.6 \mathrm{~km}^{2}$. Because of visible fruiting bodies, forest fungi have been studied for centuries, but the links between their aboveground and belowground structures have only been investigated for a few decades. Both fruiting body collections and more recent DNA analyses have helped to highlight the importance of plant communities in shaping fungal communities. An estimated $25 \%$ of all $\mathrm{C}$ in boreal forest soils is due to fungal biomass (Högberg et al. 2011), most of which belongs to mycorrhizal fungi. The types of mycorrhizal fungi vary between ecosystems, however, with boreal and tundra systems dominated by ectomycorrhizal (EM) and ericaceous mycorrhizae, respectively. The coniferous forests of the Pacific Northwest are also dominated by EM fungi, some of which produce hyphal mats that can cover $40 \%$ of the forest floor (Kluber et al. 2010). Unlike plant biodiversity that increases with decreasing latitude, the 
opposite trend is true for EM (Tedersoo and Nara 2010). Hardwood forests and ecosystems dominated by herbaceous plants tend to host arbuscular mycorrhizal fungi (AMF). Unlike EM fungi, which are represented by numerous species of basidiomycetes and ascomycetes, arbuscular mycorrhizal fungi are relatively closely related, and all belong to the glomeromycetes.

Aside from symbiotic and mutualistic fungi, both saprotrophic and parasitic fungi shape plant communities and provide important ecosystem services. Lignolytic basidiomycetes are unique in their ability to degrade lignin and are visible in forests as white rot. Additionally, basidiomycetes and ascomycetes degrade cellulose, causing brown rot in fallen wood. Fungal pathogens can dramatically alter forests, as evidenced by the death of 100 million elm trees (Ulmus spp.) in the United Kingdom and United States due to Dutch elm disease and the death of 3.5 billion chestnut trees (Castanea dentata) in the United States due to blight (Fisher et al. 2012). In addition to these historic outbreaks, numerous other pathogenic fungi are considered to be the cause of emerging infectious diseases. Since the early 2000s, spread of the laurel wilt fungus (Raffaelea lauricola) by the invasive redbay ambrosia beetle (Xyleborus glabratus) has led to widespread mortality of redbay (Persea borbonia) and other native trees in the Southeastern United States. Molecular techniques are an increasingly important tool for studying fungi, including both their mutualistic relationships and for pathogen tracking. Soil fungi are not well represented in public sequence databases, however, and it is typical to have one-third of fungal DNA sequences in a soil library match to unknown species (Smith and Peay 2014).

\section{Protists}

Protists are divided into seven key taxonomic groups: red and green algae (Archaeplastida), Amoebozoa, Opisthokonta, Stramenopiles, Alveolata, Rhizaria, and Excavata (Orgiazzi et al. 2016). Within the Amoebozoa, slime molds are one of the better studied groups and have primarily been described in temperate forests (Fig. 5.2a). These organisms have complex life cycles that involve a great deal of social interaction. During reproduction, they create complex structures that are multinucleated and visible to the naked eye (Stephenson 2011). Although many protozoa feed on bacteria, there is evidence for selective feeding. The activities of protists are not commonly included in examinations of microbial community composition (Bonkowski et al. 2009; Geisen 2016). Although larger bacteriovores such as nematodes eat patches of bacteria within the soil, protists often feed on single cells. Protists affect plant growth both directly and indirectly: directly by promoting $\mathrm{N}$ mineralization and indirectly by selective predation within the rhizosphere (Ekelund et al. 2009). Using stable isotope labeling, Crotty and others (2012) demonstrated the central role that amoebae have in the soil food web. When the researchers added labeled amoebae to both grassland and woodland soils, they were able to track that label into a wide variety of soil microfauna and mesofauna species.

\section{Microfauna}

Animals within the soils are divided according to size rather than on functional or taxonomic attributes (Coleman et al. 2018). The first grouping, microfauna, are less than $0.1 \mathrm{~mm}$ in size and include tardigrades (phylum Tardigrada), rotifers (phylum Rotifera), and nematodes (phylum Nematoda) (Fig. 5.2d). Nematodes, also known as roundworms, are ubiquitous and diverse with over 14,000 described species (Kergunteuil et al. 2016) (Fig. 5.2d). Soil nematodes specialize on many food sources. Eight different nematode feeding strategies have been described and include feeding on bacteria, fungi, plants, and other nematodes (Orgiazzi et al. 2016). These feeding strategies mean that nematodes are often found in numerous trophic levels within the soil food web (Fig. 5.1), are important to C flow, and are a link between microbes and fauna. Nematode diversity has been observed to be greater in forests compared with other ecosystems (Ettema and Yeates 2003), and forest age has a major effect on nematode communities and feeding channels (Zhang et al. 2015). Nematode community structure differs among tree species (Keith et al. 2009) and is affected by forest fire (Butenko et al. 2017) and grazing (Wang et al. 2006). In turn, nematodes can alter the fungal and bacterial communities (Blanc et al. 2006) and can enhance plant growth through increased $\mathrm{N}$ and phosphorus (P) mineralization (Gebremikael et al. 2016). Studies of nematode communities in North America have largely focused on agricultural and grassland sites, but more research on nematodes in forests is needed to fill an important knowledge gap.

\section{Mesofauna}

Mesofauna in the intermediate size range of $2-20 \mathrm{~mm}$ includes pot worms or enchytraeids (family Enchytraeidae), mites (subclass Acari), springtails (order Collembola), coneheads (order Protura), two-pronged bristletails (order Diplura), and false scorpions (order Pseudoscorpionida). Mesofauna feed on bacteria, fungi, plant detritus, and microfauna including nematodes, tardigrades, and rotifers. Enchytraeids are small segmented worms that feed primarily 
on bacteria, fungi, and, to a lesser extent, dead plant material. They are smaller than earthworms and are important members of soil communities in cold, wet ecosystems (Orgiazzi et al. 2016). Springtails are small arthropods with six legs and a short tube on their backside (cellophore) that aids in balancing fluids and electrolytes (Orgiazzi et al. 2016) (Fig. 5.2e). Springtails have been shown to preferentially feed on fungi and plants (Ruess et al. 2007), including both saprotrophic and mycorrhizal fungi. Feeding on arbuscular mycorrhizae would presumably hamper plant growth, but a recent study suggests Collembola enhance plant growth by discouraging arbuscular mycorrhizal sporulation, which in essence maintains the fungi in an active growth state (Ngosong et al. 2014). Of the approximately 7000 species of springtails (Deharveng 2004), some are found in a multitude of ecosystems and others are specialists. Across forest types, springtail communities vary by tree species, with the largest differences observed between conifers and hardwoods (Sławska et al. 2017). There are many mite species that prey on other microarthropods in forests, including springtails and coneheads that can be used as biocontrol agents for some disease-causing microorganisms and microfauna (Schneider and Maraun 2009).

\section{Macrofauna}

The macrofauna group includes ants (family Formicidae), termites (order Blattodea), pill bugs or wood lice (order Isopoda), centipedes, millipedes, pauropods, symphylans (order Myriapoda), earthworms, beetles (order Coleoptera), and numerous insect larvae (Fig. 5.2b, c, and g). To belong to this group, animals must be larger than $2 \mathrm{~mm}$.

Ants are ubiquitous and are valuable ecosystem engineers, aerating soils and increasing drainage via their underground galleries (Nemec 2014). Ant activity can also lead to an altered distribution of soil organic matter as some species bring subsoil material to the surface and bury organic matter, while other species transport large quantities of surface organic matter and fresh leaves into mineral soils (Orgiazzi et al. 2016). There are approximately 1000 species of ants native to North America (Miravete et al. 2014), and it is likely there are a few hundred introduced ants that are mostly found in urban environments. Although most ant introductions appear to have little effect on forest and rangeland ecosystem, there are notable exceptions. The introduction of red fire ants (Solenopsis spp.) from South America into the Southern United States has decreased other invertebrate populations and hindered some bird populations, and their sting can cause blindness or death in livestock (Belnap et al. 2012). Fire ants have continued to spread across the Southern United States since their introduction in the 1930s, and this invasion is estimated to cost $\$ 1$ billion annually (Pimentel 2014).
In a survey of eastern hardwood forests from Connecticut to Florida, $52 \%$ of all macroinvertebrates were ants and $45 \%$ were termites. Termites are the most numerous organisms in wood (King et al. 2013) (Fig. 5.2c). Like ants, termites are often thought of as a pest species, but termites are also the primary wood degraders in southern forests where they can consume 15-20\% of newly deposited wood over 3 years (Ulyshen et al. 2014). Not only do they directly impact the decomposition rates of woody debris, but they also alter the bacterial and fungal populations (Ulyshen et al. 2014). Both ants and termites produce antimicrobial compounds that can suppress microbial activity in decaying wood. Ulyshen and others (2014) observed that wood decomposition proceeded at the same rate in wood where macroinvertebrates were present or absent, most likely due to the suppression of the microbial population. Little research has been done that looks at the link between macroinvertebrates and microorganisms in forest and rangeland systems.

Earthworms are annelids (segmented worms) with the capacity to physically modify soils. For this reason, they are called ecosystem engineers. Earthworms have three different behavioral traits, depending on their preferred food source. Epigeic species live in leaf litter and consume fresh organic matter. Endogeic species live in the mineral soil and consume microbial biomass and other forms of organic matter within the soil matrix. Anecic species build permanent burrows and mix leaf litter with mineral soil by pulling leaves from the surface into their burrows and by casting mineral soil around these leaves. Most earthworm species, to a greater or lesser extent, are responsible for bioturbation of surface soil layers, resulting in the mixing of surfacedeposited materials with mineral soil (Orgiazzi et al. 2016). Although many ecosystems in the unglaciated portions of North America contain native earthworm populations, the invasion of earthworms has dramatically altered some US hardwood forests (see Invasive Organisms Shape Soil Biodiversity section).

\section{Megafauna}

Soil megafauna include mammals, reptiles, and amphibians. Moles (e.g., Scalopus aquaticus), voles (subfamily Arvicolinae, tribe Arvicolini), mice (Mus spp.), gophers (family Geomyidae), prairie dogs (Cynomys spp.), ferrets (Mustela putorius furo), and badgers (e.g., Taxidea taxus) are some of the most commonly known soil dwellers. These mammals dig in soil, altering the air and water flow through the soil. They may also pull food belowground, where other soil organisms may use it. Amphibians such as caecilians (order Gymnophiona) and salamanders (order Caudata) can live in or on soils and can have a major impact on dead plant litter decomposition. 
Reptiles including turtles (order Testudines), tortoises (family Testudinidae), snakes (suborder Serpentes), and lizards (suborder Sauria) often lay eggs in soil, even if the adults primarily live aboveground (Orgiazzi et al. 2016). Several species of snakes live in leaf litter or are weakly fossorial. These snakes prey on insects and other invertebrates, and the larger species prey on soil-dwelling mammals such as voles, moles, and shrews. Some of the fossorial mammals (e.g., gophers and prairie dogs) are important belowground herbivores and can have significant impacts on plant productivity and plant community dynamics in ecosystems where they are abundant. In some cases, these animals can have a significant effect on local topography by building mounds that can persist for centuries. Moles are important soil-dwelling mammals that influence the aeration of soil and also prey on multiple soil invertebrate groups (including large numbers of earthworms in some ecosystems). Their mound building activities are another important source of bioturbation when they are abundant.

\section{The Soil Habitat}

\section{Texture and Aggregation}

At the heart of the soil habitat lies a complex of structures, niches, and labyrinth-like networks of pores that vary across all spatial scales, from aggregates to landscapes, which helps to explain the unparalleled diversity of soil life (Young and Crawford 2004). One of the most fascinating and challenging realities of studying soils is their heterogeneity. For example, aerobic and anaerobic processes can occur in the same soil profile and can even take place simultaneously. Saturation can change within a few millimeters, and water can penetrate soil aggregates and create micro-anaerobic spaces in an otherwise well-drained soil. Not only are redox variations caused by water movement, but biological hot spots can quickly deplete oxygen in micropores, leading to anaerobiosis (Raynaud and Nunan 2014). Soil ecologists must constantly integrate the biological community with abiotic soil conditions to understand what an organism is likely to experience in situ.

Soil texture and structure are foundational components of the soil habitat (Fig. 5.3). Texture refers to the particle size distribution of soil minerals (sand, silt, clay), and structure is the three-dimensional arrangement of minerals, organic matter, and pore spaces into aggregates of varying size (Wall et al. 2012). Aggregate formation depends on soil organic matter, fungal hyphae, exudates, earthworm casts, roots, clay, and ionic bridging from metal ions (Bronick and Lal 2005). Categorizing microaggregates and macroaggregates (Six et al. 2000) provides a framework for understanding how the physical habitat affects soil biota. Microaggregates (20-50 $\mu \mathrm{m})$ protect soil C from decomposition and microbial biomass from predation ( $\mathrm{Li}$ et al. 2016), and they support greater microbial diversity (Bach et al. 2018). Microaggregates are also physically stable due to strong binding and cementing properties, which make them resistant to disruption from natural and anthropogenic disturbance. Macroaggregates $(>250 \mu \mathrm{m})$ are more loosely arranged and offer organisms less protection. They are also more easily disrupted by forest and rangeland disturbances (Li et al. 2016).

Pore spaces are the primary habitat for soil organisms (Fig. 5.3). Like aggregates, pore spaces differ in their size, function, and dominant organism types. Micropores $(<0.15 \mu \mathrm{m})$ exclude nearly all organisms and retain water at tensions unavailable for root uptake. Mesopores (0.15-
Fig. 5.3 A comparison of sizes of structures within soil

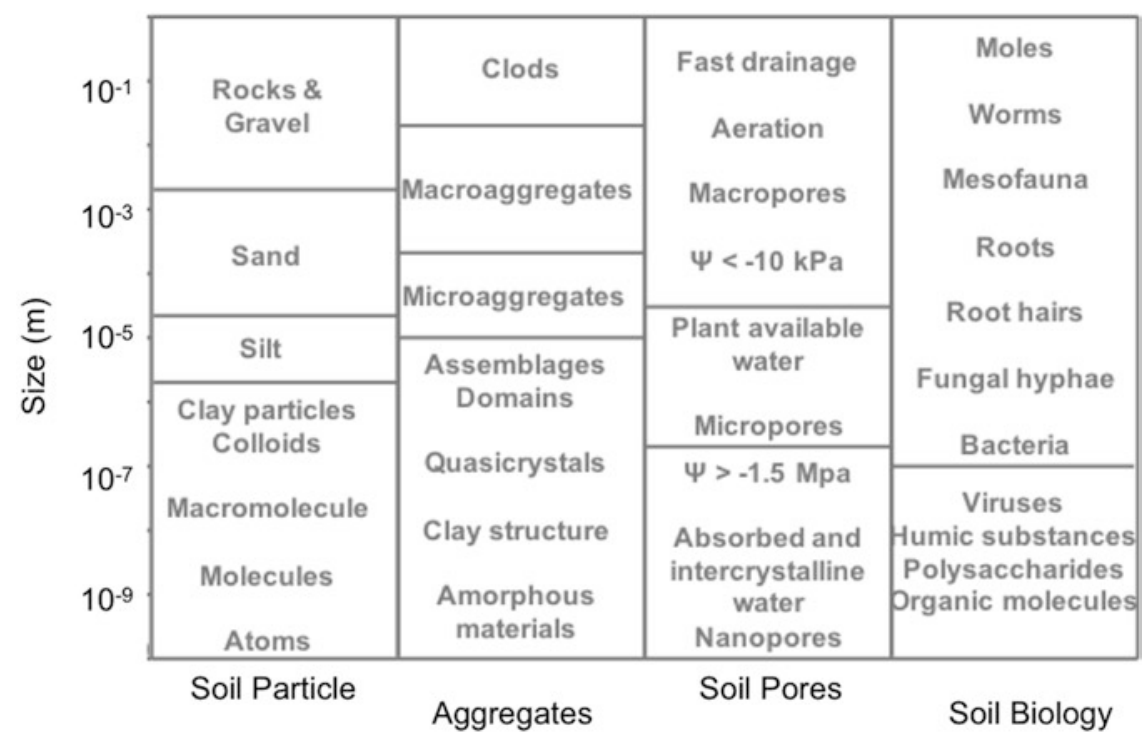


$30 \mu \mathrm{m})$ offer habitat for bacteria, fungi, and microfauna (e.g., protozoa, nematodes) and contain plant available water; macropores $(>30 \mu \mathrm{m})$ are critical for gravitational water flow and provide habitat for fungal hyphae and mesofauna. Larger soil organisms (e.g., earthworms, ants, termites) serve as soil engineers because their movement requires pushing aside and mixing soil particles. Pore size distribution regulates how water, gases, nutrients, heat, and organisms move-and thrive-in soil (Wall et al. 2012). Soil heterogeneity encourages hot spots of biological life and supports high functional redundancy (Wall et al. 2012; Wilhelm et al. 2017a). Organisms may be physically isolated from adjacent predators or resource competitors, sequestered in the safety of small pores, or, alternatively, may be left to experience cosmopolitan life and death where sufficient pore size continuity exists. The arrangement and total volume of pore space moderates the microclimate for soil organisms (Jury et al. 1991). Consequently, temperature fluctuations are greatest near the soil surface and are quelled with soil depth by the insulating effect of soil pores (Busse et al. 2010).

Generalizations about the soil physical habitat and its influence on soil biodiversity can be made. For example, coarse-textured sandy soils support organisms that are best adapted to moisture- and nutrient-limiting stresses. Finer-textured soils provide a greater variety of structural habitat, leading to comparatively high diversity of soil organisms. Generalizations are not always helpful, however, because of unpredictable interactions of the physical habitat with climate, topography, plant communities, time, and site disturbances. Consequently, inferences about habitat conditions and their relationship to forest and rangeland soil biodiversity are still unfolding and are best viewed on a site-by-site basis.

\section{Soil Chemistry}

As primary minerals weather into clays, charged surfaces and cation exchange capacity increase. Soil organic matter sticks to mineral surfaces, and the accumulation of both clays and organic matter leads to increased hydrogen ions $\left(\mathrm{H}^{+}\right)$in soil solution. Numerous studies report that microbial composition correlates to soil pH (Fierer and Jackson 2006; Fierer et al. 2009). Soil pH is determined by the many biochemical reactions and mineralogy of the soil (Fernández-Calviño et al. 2011). The relationship between the soil biota and mineralogy likely changes with ecosystem age. It has been hypothesized that biology shapes mineralogy in early ecosystem development. For example, lichens secrete organic acids that solubilize minerals for nutrient acquisition. As the ecosystem ages, however, some nutrients are lost from the system, and such deficiencies restrict the biota (Brantley et al. 2011).

Minerals differ in their molecular composition and can be preferentially weathered by soil biota. The best-known examples of this weathering involve the actions of mycorrhizal fungi, which are capable of weathering P-containing minerals (Quirk et al. 2012). Bacteria can also colonize specific minerals. For example, bioleaching takes advantage of sulfate reducers that colonize minerals that contain iron $(\mathrm{Fe})$ and sulfur (S) as a means to recover precious metals (Hutchens 2009). Although acquisition of nutrients in acidic forest soils has primarily been ascribed to mycorrhizal associations, aerobic bacteria colonize minerals such as biotite, making Fe and P more plant available (Uroz et al. 2009). Bioturbation of soil by animals can result in subsoils being brought to the surface where they are exposed to surficial weathering processes. Furthermore, the passage of soil through the earthworm gut results in a significant increase in mineral weathering rates (Carpenter et al. 2007; Resner et al. 2011).

Heavy metals can also impact forest and rangelands. In forests they can alter the understory (Stefanowicz et al. 2016) and the soil biota (Tyler et al. 1989). There are about 50,000 US locations that have metal concentrations higher than the normal range of $1-6.5 \mathrm{ppm}$ (Bothe and Słomka 2017). The United States spends \$6-8 billion annually remediating metal-contaminated areas (Gall et al. 2015). The patchy nature of effects of heavy metal concentrations and bioavailability make it difficult to track toxicity and quantify ecosystem effects. Laboratory-based studies have assessed bacterial toxicity levels, but they do not correspond to in situ measurements (Giller et al. 2009). Impacts of heavy metals on the soil microflora usually include a decrease in microbial biomass and a shift in community composition (Gall et al. 2015), and although metals can be distributed across the soil food web, heavy metal tolerance varies greatly. For example, earthworms and oribatid mites appear sensitive to heavy metals, but springtails are more tolerant (Tyler et al. 1989).

\section{The Rhizosphere}

The rhizosphere, the soil that surrounds and is influenced by a plant root, hosts a large number of biogeochemical processes. Due to the inherent complexity and diversity of plant root systems, the rhizosphere is not a region of definable size or shape but rather includes gradients of chemical, biological, and physical properties that change both radially and longitudinally along the root (Fig. 5.4). Roots can release $10-250 \mathrm{mg} \mathrm{C} \mathrm{g}^{-1}$ annually or about $10-40 \%$ of their total photosynthetically fixed C (Jones et al. 2009). 
Fig. 5.4 A cross-sectional view of the association of microorganisms with the rhizosphere or root zone of the Arabidopsis plant. (Photo credit: Scanning electron microscope image captured at the U.S. Department of Energy's Environmental Molecular Sciences Laboratory, Richland, WA, and colorized by Alice Dohnalkova)

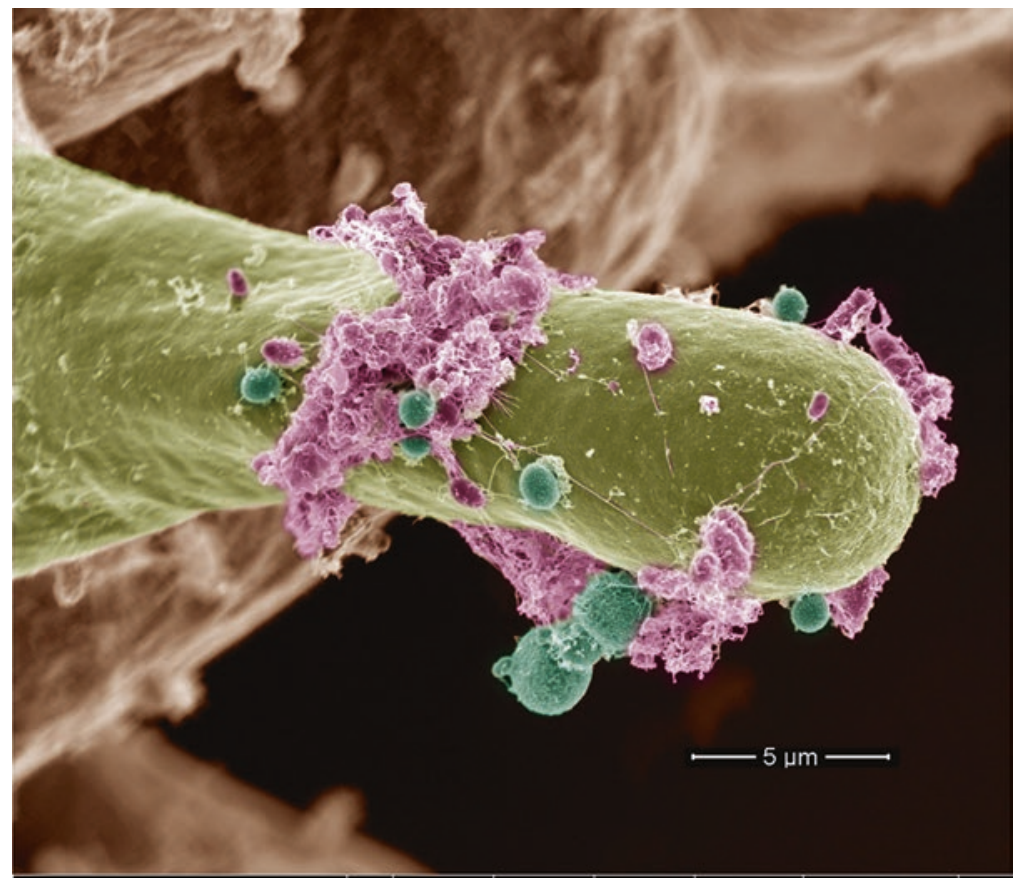

The composition and quantity of released compounds can be influenced by plant species, canopy position, climatic conditions, herbivory, nutrient deficiency or toxicity, and properties of the surrounding soil. Secreted compounds include organic acids, amino acids, proteins, sugar, phenolics, and other secondary metabolites that are readily available substrates for soil microorganisms. These compounds influence rhizosphere processes, including nutrient acquisition (e.g., acquisition of $\mathrm{Fe}$ and $\mathrm{P}$ ), allelopathy, chemotaxis (e.g., between rhizobia and legumes), and the promotion of colonization of beneficial microbes on root surfaces (e.g., Bacillus subtilis, Pseudomonas fluorescens) (Bais et al. 2004; Park et al. 2004).

The root system architecture is determined by plant species as well as the biotic and abiotic soil conditions. The distribution of nutrients in soils is heterogeneous, and plants can modify their morphology when they sense the presence of nutrients. They are able to allocate more resources to the root system and direct root growth. For example, rangeland grasses such as the invasive cheatgrass (Bromus tectorum) have great root plasticity, allowing it to quickly take advantage of nutrient-rich patches (Arredondo and Johnson 1999). Nutrient acquisition from calcareous soils involves rhizosphere processes, such as the exudation of phosphate-mobilizing carboxylates (Hinsinger 2001) or the release of Fe-chelating phytosiderophores (Ma et al. 2003; Robin et al. 2008).

A growing body of research points to the influence the plant rhizosphere has on shaping the legacy of the soil microbial community (Philippot et al. 2013a) and nematode diversity (Keith et al. 2009). There is evidence for a long-term, evolutionary dimension to the interactions between plant roots, microorganisms, and soil in the rhizosphere (Lambers et al. 2009). Aside from the role that these interactions have in cropping systems, there has been a recent interest in how rhizosphere dynamics may influence restoration success (Kardol and Wardle 2010; Philippot et al. 2013a). Reestablishing mutualistic relationships and limiting pathogen load are now acknowledged components of restoration efforts.

\section{The Impact of Disturbance on Soil Biodiversity}

\section{Compaction}

Maintaining adequate soil porosity is one of the most important objectives of forest soil management (Powers 2006), with long-standing guidelines for disturbance thresholds established for many forests. Soil compaction and rutting during harvesting are of concern, as they often alter total porosity, pore size distribution, and pore continuity and can lead to detrimental changes in soil quality and plant productivity (Powers et al. 2005). It is common to find compactioncaused declines in macroporosity following harvesting, with concomitant increases in mesoporosity and microporosity as large pores are reduced in size (Shestak and Busse 2005). Because of reduced macroporosity, slower rates of water infiltration and related effects on erosion potential, waterlogging in clay soils, and indirect changes in soil life may result. In addition, the collapse of macropores represents a 

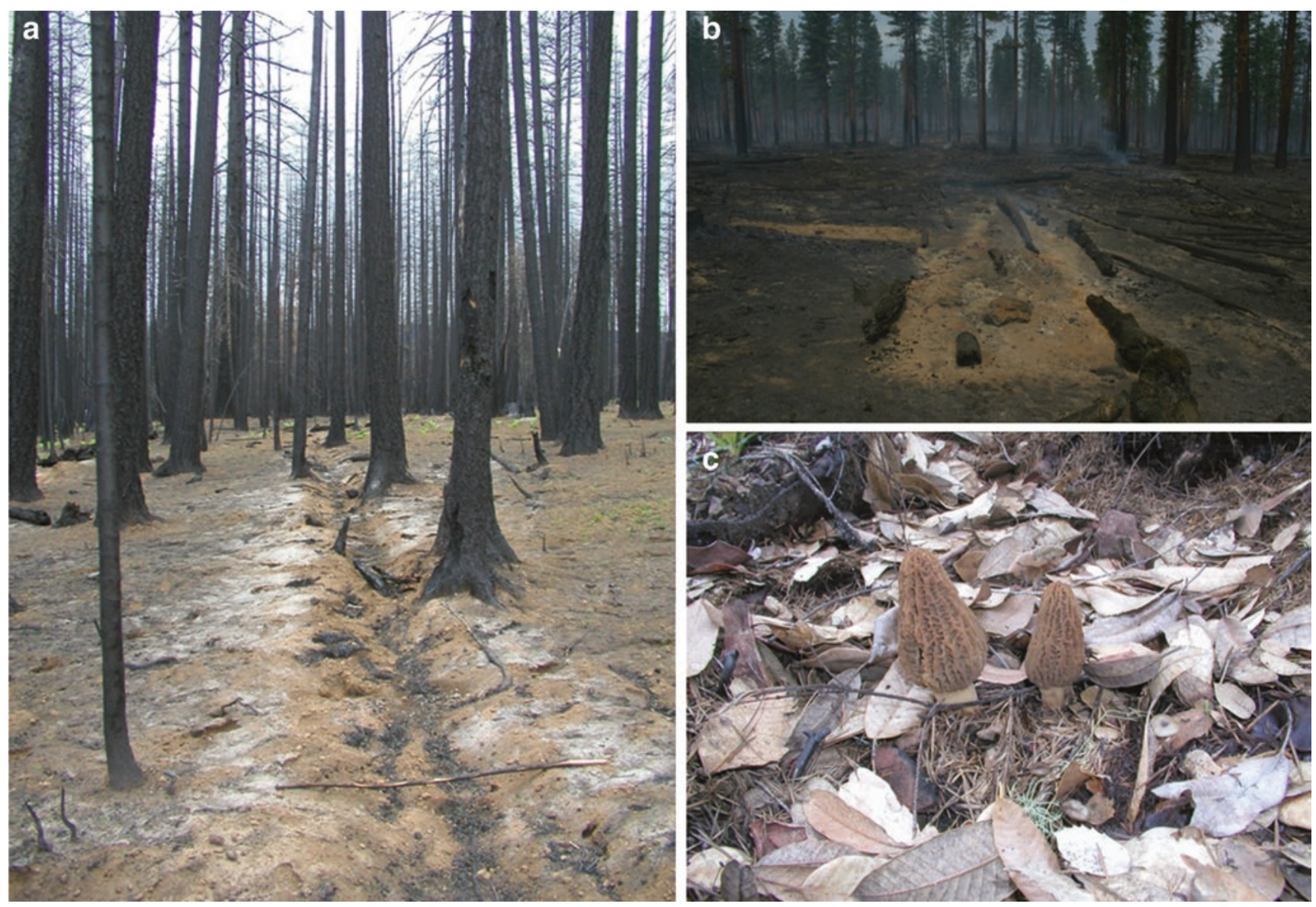

Fig. 5.5 (a) In 2003, the B\&B Fire burned over 36,422 ha in the Deschutes and Willamette National Forests, Mount Jefferson Wilderness, and the Warm Springs Reservation in Central Oregon. In some areas, entire logs were consumed by the fire. The intense heat generated by the burning of large woody material causes soil oxidation, conspicuously changing the soil color from black to various shades of red. High-severity fires that consume entire logs or stumps affect relatively small areas but can have profound soil impacts. After a severe fire, soils may be void of almost all biological activity, and the length of time for recovery is unknown. (Photo credit: Doni McKay, USDA Forest Service.) (b) Postburn photo of a high-intensity soil burn treat-

loss of habitat for soil macrofauna and mesofauna, leading to reductions in abundance and diversity (Battigelli et al. 2004). Disturbance is often unavoidable, yet it can be moderated by using best management practices, such as operating on designating skid trails or on the surface of frozen or dry soil (Craigg et al. 2015). Long-standing federal guidelines recommend limiting compaction to less than $15 \%$ of the land on an aerial basis (Page-Dumroese et al. 2000). However, many regions have scrapped this well-intentioned yet ineffective guideline because it does not account for slope, microtopography, or variable patterns of surface and subsurface water flow.

Compaction and soil disruption present similar challenges in rangeland systems. In the intermountain West, cattle grazing has impacted riparian soils, leading to bank ment applied by the combustion of a parallel stack of large downed logs in spring 2013 at the Pringle Falls Experimental Forest, Deschutes National Forest in Central Oregon (Cowan et al. 2016; Smith et al. 2016). (Photo credit: Ariel D. Cowan, Oregon State University, used with permission.) (c) The photo shows postfire morels (Morchella spp.) fruiting among the leaves of tanoak (Notholithocarpus densiflorus) in the spring following the 2002 Biscuit Fire, a massive wildfire that burned nearly $202,343 \mathrm{ha}\left(2020 \mathrm{~km}^{2}\right)$ in the Siskiyou National Forest in Southern Oregon and Northern California. (Photo credit: Jane E. Smith, USDA Forest Service)

erosion, bank compaction, and breaking up of soil crusts (Box 5.2). The Taylor Grazing Act of 1934 put in place guidelines for grazing on public lands, but the balance between grazing and ecosystem protection remains a contentious issue. One long-term study observed that heavy grazing leads to a loss of soil $\mathrm{C}$ and to changes in the microbial community (Ingram et al. 2008). Globally, grazing by large herbivores, such as cattle (Bos taurus), moose (Alces alces), or yak (Bos grunniens), decreases soil fauna and microbes, but the magnitude of the response varies by biome (Andriuzzi and Wall 2017). In a longterm experiment, trampling resulted in a decrease in bacterial biomass and a shift particularly in cyanobacterial communities, with a decrease in those that fix N (Steven et al. 2015). 


\section{Postfire Biodiversity}

Wildfires are a common large-scale disturbance that differentially affects soil communities and productivity, largely depending on soil burn severity (Certini 2005). Most fires are of mixed severity and create a mosaic of burned and unburned patches on the landscape (Keeley 2009; NWCG 2003) (Fig. 5.5a, b). Many soil inhabitants have evolved to live with and survive mixed severity fire. For example, amphibians will burrow into the ground, hide in moist logs, or take cover under rocks. Springtails are able to migrate to deeper soil horizons (Malmström 2012).

Soil microbes tend to congregate in the upper soil profile where nutrient concentrations are the highest (Oliver et al. 2015), yet they respond quickly to ecosystem disturbances caused by fire (Barker et al. 2013; Hebel et al. 2009; Smith et al. 2004, 2005, 2017). When large downed wood burns, the soil beneath is exposed to prolonged, intense heat, which can reach temperatures that exceed the lethal threshold for fine roots and most soil organisms (Busse et al. 2013; Smith et al. 2016). High-severity fires may burn at soil surface temperatures exceeding $300{ }^{\circ} \mathrm{C}$ (Smith et al. 2016) and can cause partial to total vegetation mortality aboveground and complete or near-complete loss of belowground soil microbes in the top $10 \mathrm{~cm}$ of the soil profile (Hebel et al. 2009; Smith et al. 2017). Soil microbial community responses to high-intensity fires tend to be longer lasting and more extreme. On the other hand, in forest ecosystems that are managed under frequent fire regimes (e.g., Southeastern United States), fire alters soil microbial composition but does not affect total diversity (Brown et al. 2013; Oliver et al. 2015). The fires in such ecosystems are generally lower in severity, due to lower fuel loads. Lowseverity fires typically produce temperatures below $100{ }^{\circ} \mathrm{C}$ at the surface. These fires mostly remove smaller shrubs and small-diameter trees and leave larger trees. The soil microbes below a soil depth of $5 \mathrm{~cm}$ remain intact (Cowan et al. 2016; Reazin et al. 2016). Intact EM fungal communities may contribute to the regeneration success and resilience of forests (Cowan et al. 2016). Fire stimulates the appearance of phoenicoid fungi (Carpenter and Trappe 1985), particularly members of the order Pezizales, which commonly start fruiting as soon as a few weeks after fires and continue to fruit for up to 2 years (Adamczyk et al. 2012; Fujimura et al. 2005; Petersen 1970; Warcup 1990; Wicklow 1975). Morels (Morchella spp.) are well-known members of the Pezizales (Fig. 5.5c). Springtails may recover from low-intensity fires after a few years, but highintensity fires may lead to a long-term shift from fungal to bacterial feeding species (Malmström 2012). The patchiness of fire has also been shown to increase the diversity of forest macrofauna that include members of spiders (order Araneae), isopods, centipedes (class Chilopoda), milli- pedes (class Diplopoda), and click beetle (family Elateridae) larvae (Gorbunova et al. 2017).

Environmental change and fire suppression throughout the twentieth century in the Western United States have created conditions that facilitate high-intensity forest fires (Hessburg et al. 2015). The presence and amount of large down wood influence the extent of extreme soil burning (Busse et al. 2013; Smith et al. 2016). A greater emphasis on restoring and maintaining healthy landscapes and the ecological benefits of fire has increased interest in prescribed fire and manual removal of woody materials from forested areas to decrease fire severity. Studies are ongoing to determine whether soils that experience severe fires remain on a unique soil community trajectory that distinguishes them from areas that burn simultaneously but at a lower intensity or whether both fire intensities converge to a system state similar to that preceding the fire disturbance (Reazin et al. 2016).

\section{Invasive Organisms}

Invasive organisms are the second most common cause of native species loss, after habitat destruction (Wilcove et al. 1998). In the case of plant invasion, there are numerous plant-soil feedbacks that affect both the ability of the plant to invade and the composition of the soil community, especially in the rhizosphere. For example, a plant's relationship with mycorrhizal fungi can affect its ability to invade a new ecosystem. If the plant has an obligate symbiosis, it is limited by the distribution of the symbiont (Pringle et al. 2009). Invading plants that lack symbiotic relationships can disperse to a new environment, and once established, they can also affect symbiotic relationships of native plants. For example, in grassland soils invaded by cheatgrass, the arbuscular mycorrhizal communities changed in nearby native species (Hawkes et al. 2006). Disruption of the mycorrhizal networks can lead to differences in plant characteristics and ecosystem functions.

The impact that invasive plants have on the soil community, particularly the rhizosphere community, is likely complex and variable between individuals and their location (Coats et al. 2014). Japanese barberry (Berberis thunbergii) is an invasive shrub common throughout northeastern United States forests. The ability of this shrub to invade appears to be most influenced by land use legacy, including reforestation following agriculture (DeGasperis and Motzkin 2007). The growth of Japanese barberry has been shown to alter microbial community composition and function, in part by altering $\mathrm{N}$ cycling and also by increasing soil pH (Kourtev et al. 2002). The shrub has additionally been observed to increase the density of earthworms, with the species of worms matching nonnative European species (Kourtev et al. 1999). 
Invasive European earthworms (suborder Lumbricina) arrived in North America with European settlers, ship ballast, and ornamental plants (Bohlen et al. 2004; Hendrix et al. 2008). Deforestation in the eastern United States led to habitat loss, which greatly reduced native earthworm populations and facilitated the spread of a dozen European species. Prior to colonization by European species, the hardwood forests of Canada, the Great Lakes region, and New England had been earthworm-free since the end of the last glaciation thousands of years ago (Hendrix 1995). However, since the 1990s, invasive European earthworms have invaded these earthworm-free forests, causing dramatic changes in the forest floor and soil habitats (Bohlen et al. 2004). These impacts have been exacerbated by the recent spreading of three co-invading Asian earthworms (Metaphire hilgendorfi, Amynthas agrestis, and Amynthas tokioensis) (Chang et al. 2018) whose range expansion in the last 15-20 years may have been facilitated by recreational fishing, off-road vehicles, and the transportation of compost, horticultural waste, and mulch (Bellitürk et al. 2015; Chang et al. 2017). Environmental factors including soil properties and litter inputs play an important role in determining the abundance of invasive earthworms (Crumsey et al. 2014; Szlávecz and Csuzdi 2007). Recent studies have also shown that white-tailed deer (Odocoileus virginianus) abundance increases invasive earthworm abundance (Dávalos et al. 2015).

In North American forests, the presence of invasive earthworms has led to major changes in vegetation, physical and chemical soil properties, and biogeochemical cycles. They are associated with declines in plant diversity and are known to change plant community composition in favor of graminoids and nonnative plants (including Japanese barberry) over native species (Craven et al. 2017). Through feeding, burrowing, and casting, invasive earthworms reduce the understory vegetation and leaf litter layer (Dempsey et al. 2011; Dobson and Blossey 2015; Hale et al. 2005, 2006; Nuzzo et al. 2009) and cause soil mixing and translocation of forest floor $\mathrm{C}$ from the $\mathrm{O}$ horizon into the soil, resulting in increased litter decomposition rates, a thicker A horizon, and increased aggregate formation (Bohlen et al. 2004; Greiner et al. 2012; Snyder et al. 2011; Szlavecz et al. 2011). Nonnative earthworms change the size of various $\mathrm{C}$ and $\mathrm{N}$ pools in the soil (Fahey et al. 2013; $\mathrm{Ma}$ et al. 2013; Yavitt et al. 2015) and increase $\mathrm{CO}_{2}$ and nitrous oxide $\left(\mathrm{N}_{2} \mathrm{O}\right)$ efflux (Eisenhauer et al. 2007). Their activity also affects soil nutrient (calcium, magnesium, potassium, and phosphorus) concentrations (Resner et al. 2015) and increases soil $\mathrm{pH}$.

Altogether, these changes in the soil habitat profoundly affect soil microfauna and mesofauna. By eliminating the thick leaf litter layer (O horizon) on the soil surface, invasive earthworms reduce fungal biomass and increase the ratio of bacteria to fungi (Dempsey et al. 2011, 2013). However, reported results from case studies describing impacts on microbial biomass in the overall soil profile have ranged from positive (Groffman et al. 2004, 2015), to neutral (Snyder et al. 2011), to negative (Eisenhauer et al. 2007). Some of the observed differences can likely be attributed to earthworm species identities and interspecific interactions (Chang et al. 2016). By changing the soil structure, soil organic matter properties, and soil microbial community, invasive earthworms may change $\mathrm{C}$ use efficiency of soil microbes, increase soil microbial biomass carrying capacity, and promote C metabolism (Dempsey et al. 2013; Groffman et al. 2015). In general, they also have negative impacts on soil microarthropods, such as springtails and mites (Eisenhauer et al. 2007; Gao et al. 2017).

\section{Climate Change and Belowground Biodiversity}

Climate change effects include a number of specific conditions that directly and indirectly alter the soil biota. Three conditions that have been measured across multiple ecosystems are $\mathrm{CO}_{2}$ enrichment, increased temperature, and altered precipitation patterns. A meta-analysis comparing 75 soil biology studies found that altered precipitation results in the most dramatic and consistent effects across ecosystems (Blankinship et al. 2011). Increased precipitation resulted in an increase in biomass for microbiota and fauna, but the size of the effect was larger in drought conditions. Especially in forested systems, drought can result in lower biomass (Blankinship et al. 2011) and a decrease in the rate of litter decomposition (Lensing and Wise 2007). One reason for the more dramatic effect in forest ecosystems may be related to a greater degree of desiccation of the litter layer (Keith et al. 2010). When precipitation was increased in a rangeland experiment, visible soil crusts decreased, but cyanobacteria increased in DNA analysis, suggesting that altered precipitation in dry ecosystems may dramatically change the basic soil community structure (Steven et al. 2015).

In the case of $\mathrm{CO}_{2}$ enrichment, shifts in microbial and microfauna populations have been observed in some cases, but not others (Blankinship et al. 2011; GarcíaPalacios et al. 2015). In the decade-long Free Air $\mathrm{CO}_{2}$ Enrichment (FACE) experiments, differences in responses were also noted between deciduous and coniferous forests. During the early years of the studies, net primary production increased, but later the coniferous forests became increasingly $\mathrm{N}$ limited, and net production decreased. This was not true of the deciduous forest, which continued to experience enhanced net primary production (Walker et al. 2015). The $\mathrm{CO}_{2}$ enrichment also did 
not lead to increased mycorrhizal colonization in the conifers at the FACE site (Pritchard et al. 2014), although increased mycorrhizal biomass has been observed in other studies (Treseder 2004). The complexity of responses associated with $\mathrm{CO}_{2}$ enrichment in part stems from varying responses across different taxa and functional groups (García-Palacios et al. 2015); for example, increased abundance of detritivores but not herbivores has been noted across multiple studies (Blankinship et al. 2011).

Higher soil temperatures increase the rate at which soil organisms decompose and respire organic matter (Zhang et al. 2005), including $C$ that has persisted in the soil organic matter pool (Briones et al. 2010; Treseder et al. 2016). These functional changes are accompanied by shifts in the soil biota. García-Palacios and others (2015) observed an increase in fungal biomass when a grassland was warmed, and others have reported a similar shift in favor of fungi over bacteria (Zhang et al. 2005). More detailed phylogenetic analysis has not yielded consistent results across ecosystems, with numerous microbial functional and taxonomic groups changing in abundance in different studies (Pold and DeAngelis 2013). Differences in plant response likely contribute to these varying results, but these crossecosystem comparisons are also complicated by the use of different analytical methods across studies.

\section{Forest Management}

\section{Harvesting}

Recent results from a long-term soil study in North American offer keen insight on the effects of forest harvesting on soil microbial diversity. The Long-Term Soil Productivity (LTSP) study was installed in the early 1990s in coniferous and hardwood forests across the United States and Canada, with the goal of understanding the effects of clear-cut harvesting and site preparation disturbance on soil and vegetation productivity (Powers 2006). Common treatments across sites included soil compaction (none, moderate, severe) and biomass removal during harvesting (bolewood only, whole tree, whole tree plus forest floor). Exhaustive genetic analysis of bacterial and fungal communities identified numerous changes in community composition, including the loss of EM fungal diversity and an increase in heat- and desiccationtolerant organisms in harvested plots across 18 North American sites (Wilhelm et al. 2017b). The majority of taxa, however, were unaffected by harvesting, leading the authors to state, "Changes resulting from harvesting were relatively minor in comparison to the variability between soil layers and among geographic regions." Results specific to subboreal LTSP sites also discovered that harvesting produced a patchy distribution of fungal populations (Hartmann et al.
2012), stronger effects of compaction on fungal than bacterial communities (Hartmann et al. 2012), modest effects of harvesting on hemicellulolytic populations (Leung et al. 2016), and distinct changes in microbial communities responsible for organic matter decomposition (Cardenas et al. 2015).

It is interesting to compare these results with the 10-year vegetation responses across the long-term soil productivity study network and ask whether there is a common or parallel response between soil and plant communities. Unlike the varied responses shown by soil communities, few changes in vegetation growth have been found across the network of sites and treatments (Ponder et al. 2012). Cardenas and others (2015) suggest that "soil microbial communities are more sensitive than above-ground biomass to harvesting and might be responsive indicators of disturbance." This also reaffirms that the link between soil biodiversity and forest function or productivity has not been conclusively established (Grigal 2000) and that it remains an important area for continued research.

\section{Fuel Reduction Practices (Burning, Thinning, Mastication)}

Wildfire mitigation is a priority in United States forests and rangelands, with thinning and burning the most common best management practices in use. These treatments are designed to (1) reduce hazardous fuel loads, (2) lessen wildfire severity and spread, (3) improve forest health and resilience to natural disturbances, and (4) improve forest productivity. Any ecological consequences affecting soil biodiversity are unintentional yet require scrutiny. For example, in a meta-analysis of 139 published studies of forest disturbance, Holden and Treseder (2013) identified a nearly $30 \%$ reduction in soil microbial biomass due to both natural and management-caused disturbances, including thinning and prescribed fire.

Most evidence from United States forests points to benign or transient effects of single-application thinning or burning on soil microbial diversity and function (Grayston and Rennenberg 2006; Overby and Gottfried 2017; Overby and Hart 2016; Overby et al. 2015). In the case of fungal diversity, Cairney and Bastias (2007) note that treatment effects are site specific and, in particular, fire-intensity specific, with community responses greatest in the upper soil horizons. Repeated burning, by comparison, has been shown in separate studies to produce positive changes that favor fire-selected fungal communities (Oliver et al. 2015) and reduced activity of cellulolytic fungi that help drive soil C turnover (Bastias et al. 2009).

A recent study of ponderosa pine (Pinus ponderosa) forests in Central Oregon provides insight on the importance 
of fire intensity and time since burning on soil fungal community responses. Treatments included high-intensity burning of log piles, low-intensity broadcast burning, and an unburned control (Cowan et al. 2016). Within 1 week of burning, a strong response in fungal community turnover favoring ascomycetes and fire-responsive populations was found on high-intensity plots, whereas low-intensity broadcast burning showed only moderate changes relative to the control (Reazin et al. 2016). Within 1 year of burning, however, little difference in EM fungal richness, diversity, or composition was found among treatments (Cowan et al. 2016), suggesting that there is value in mixed severity burning to ensure the survival of fungal refugia and meet fuel reduction objectives. Other studies have noted a variety of postfire responses by EM communities, ranging from essentially no change to substantial changes in community composition, with no consistent trend relative to fire intensity (Glassman et al. 2016; Smith et al. 2004; Southworth et al. 2011; Trappe et al. 2009).

\section{New Approaches to Understand Soil Biodiversity}

Methods used to study soil biodiversity have changed dramatically in the last several decades. The most significant of these changes has been the adoption of molecular methods that target the biomolecules that compose the soil and the increasingly sophisticated techniques to analyze the biomolecules so as to better describe the soil community. By the early 2000s, most soil microbiology laboratories had begun to include measurements of lipids or DNA fingerprinting, but technologies were such that even a few hundred sequences were considered a large number, even though it was suspected this was far from representative of the community. With today's increased accessibility to next-generation sequencing (Metzker 2010), most microbial DNA studies now include several thousand sequences per sample, and more studies of soil fauna include sequencing to assess biodiversity (Creer et al. 2016). This shift toward sequencing has resulted in new challenges associated with data storage and interpretation, and a new generation of soil biologists is spending more time coding than peering through a microscope. These new tools provide great opportunities and allow the community to ask new and exciting questions: Which organisms are active? What are the functions of all the organisms that we have sequenced but have not cultured or observed extensively? How many cryptic species are there? When does soil biology composition influence soil function? How do we determine the appropriate scale for study?

Over the next several years, we will undoubtedly continue to see studies that take a molecular approach, but those studies will go beyond characterizing communities based solely on ribosomal DNA. We will see increased emphasis on connections of structure and function. One avenue for exploring function is through the use of shotgun metagenomics. This method has been applied to examine the abundance of broad classes of functional genes (Myrold et al. 2014). For example, Uroz and others (2013) characterized the organic horizon soil of Norway spruce (Picea abies) as being enriched in genes that degrade carbohydrates compared to the mineral horizon, and soil samples representing a range of different $\mathrm{pH}$ were analyzed to determine the physiological adaptations to acid and basic conditions (Malik et al. 2017). Recently, mitochondrial metagenomic analysis has been used to study soil animals and, among other findings, has revealed Collembola dispersal patterns in forested islands (Cicconardi et al. 2017).

Sequencing that targets DNA is only one of many methods collectively referred to as "omics." Targeting messenger RNA, the community's transcriptome, can be used to determine short-term responses, such as the genetic interplay between tree roots and newly colonizing mycorrhizae (Kurth et al. 2015). The first report of a soil metatranscriptome was from a method development study designed to elucidate the functional diversity of eukaryotic microorganisms in forest soil (Bailly et al. 2007). Among the complementary DNA (cDNA) sequences recovered, phosphate transporters, and glutamine synthetases, researchers gained a new understanding of nutrient acquisition. The key feature of metatranscriptomic analysis involves random sequencing of microbial community RNA in the absence of predefined primer or probe specificity; metatranscriptomics thus has a great potential for the discovery of novel genes.

Enzyme activity within soil has been studied by measuring degradation of specific organic molecules since the nineteenth century, but new technologies can target the protein molecules themselves (Bastida et al. 2009). Metaproteomics was used to identify the fungal enzymes important in litter decomposition and uncovered the seasonal shift from ascomycetes to basidiomycetes (Schneider et al. 2012). Both soil metaproteomics and metabolomics (Koek et al. 2006; Kind et al. 2009) are still under development, but both are promising tools that will be applied in the near future to better link microbial communities to function.

Aside from using molecular methods alone, several studies have linked molecular methods with stable isotopes to target specific functional communities. By using labeled substrates (e.g., ${ }^{18} \mathrm{O},{ }^{13} \mathrm{C}$, or ${ }^{15} \mathrm{~N}$ ), stable isotope probing (SIP) distinguishes metabolically active members of a soil community from the inactive ones. Sufficient incorporation of the label into the biomolecule of interest (e.g., lipids, nucleic acids, proteins) allows the "heavy" fraction to be separated from the "lighter" one. Stable isotope probing identifies active consumers in environmental samples (Dumont and Murrell 2005), linking metabolic capacity to phylogenetics 
(Hungate et al. 2015) and genomics (Chen and Murrell 2010). The SIP method has already been applied to examine some food web structures. For example, the microbes associated with methanotrophic communities were tracked using DNA-SIP (Maxfield et al. 2012), and Collembola eating habits were investigated using labeled lipids (Menzel et al. 2017). A rapidly developing area of research combines molecular gut content analysis, stable isotope technique, and fatty acid analysis. This approach was used to investigate feeding group, trophic level, or food resource preference of earthworms (Ferlian et al. 2014; Chang et al. 2016), Collembola (Ferlian et al. 2015), and mites (Pollierer et al. 2009). With high-throughput sequencing, molecular gut content analysis will be a much more powerful tool for understanding basic predator-prey connections.

The technologies described here will undoubtedly continue to shape the study of soil biodiversity. Future progress in sequencing technologies and analysis may lead to powerful alternative strategies, such as combining mRNA-SIP with metatranscriptomic analysis (Dumont et al. 2011; Jansson et al. 2012). Higher-resolution sequencing in space and time will allow researchers to apply network analysis (Faust and Raes 2012) and structural equation modeling to community analysis so as to uncover novel interactions between community members and their environment. These new methods should not be adapted at the expense of methods used to better describe species, however. A large number of soil microbes still exist that have not been cultured or characterized, and there is dwindling expertise in soil invertebrates, including microfauna. As new molecular technologies open many exciting avenues, it should also be a priority to retain taxonomic knowledge and pass it to a new generation of scientists.

\section{Conclusions}

The forest and rangeland soils of the United States are home to a myriad of biological diversity. Diverse soil habitats, encompassing a spectrum of nutrient availability, moisture content, gas diffusion, pore sizes, and inputs from the surface, provide ample spaces for biological specialization and interaction. These habitats are dynamic through time as well, responding to natural and humangenerated disturbances, such as compaction, wildland fire, invasive species, and climate change. People shape these biological interactions through how we choose to manage forests and rangelands. Although definitive evidence linking biodiversity responses to management practices is far from complete, we know that changes in microbial species richness, diversity, and community composition are common consequences of management practices. Intensive harvesting leads to greater changes in biodiversity compared to less-intense practices such as thinning, and the strongest biodiversity effects are seen in the $\mathrm{O}$ horizon and the upper mineral soil. Short-term changes in biodiversity ( $0-5$ years postdisturbance) can be expected, but long-term responses are less common, suggesting community resilience (Box 5.1).

Recent molecular methodological advances have increased knowledge of soil biodiversity, especially microorganisms. Yet challenges remain to identify active soil communities, interactions among organisms and trophic levels, and functional importance to the whole ecosystem. Improved understanding of biological interactions within soil is key to sustaining and protecting our forests and rangelands now and for the future. Increased knowledge of the soil biodiversity has the potential to improve functional predictions. A recent meta-analysis of 82 environmental datasets revealed that $44 \%$ of variations in process rates could be explained by environmental variables such as temperature, moisture, and $\mathrm{pH}$, but in most cases, models for $\mathrm{C}$ and $\mathrm{N}$ cycling were improved when microbial community data were included (Graham et al. 2014). The challenge for the next several years will be determining the best biological parameters to measure and exactly how to integrate those data into existing and new models.

In a rapidly changing world, there has been a great deal of conversation about biodiversity loss. This conversation has focused on plants and animals, and it remains an open question if we are also losing soil biodiversity. Overall, high levels of belowground biodiversity do not necessarily correspond with hot spots of aboveground biodiversity, such as the Tropics. This means prioritizing conservation efforts to areas with high aboveground biodiversity may not protect soil organisms and the benefits we derive from their interactions and resulting ecosystem functions and services. A recent meta-analysis of soil biodiversity studies concluded that because of functional redundancy, a loss of biodiversity is not likely to lead to changes in the $\mathrm{C}$ cycle unless key organisms are lost (Nielsen et al. 2011). The problem with this conclusion is we lack a clear understanding of what those key organisms might be, and gaining this knowledge will likely take many more years of research. In the meantime, should we protect soil biodiversity? Likely the functional redundancy in soil does increase its resistance and resilience, and if we continue neglect protections for soil biodiversity, we run the risk of losing key species before they are recognized (Turbé et al. 2010).

\section{Key Findings}

- Soil is home to a myriad of biological diversity, accounting for about $25-30 \%$ of all species on Earth. Community members range vastly in size, mobility, ecological function, and response to disturbance, and collectively they flourish in a multitude of physical and chemical soil habitats. 
- Changes in species richness, diversity, and community composition are common consequences of management practices. Although short-term changes $(0-5$ years postdisturbance) can be expected, long-term responses are still unknown.

- Intense harvesting and severe burning lead to greater changes in species diversity and community composition compared to less-intense practices such as thinning or low-severity prescribed burning. Best management practices that limit soil compaction, severe soil heating, and exposure of bare mineral soil help to sustain community diversity and resilience.

- Major disturbances such as wildfire, invasive plants and animals, and climate change are likely to modify the health and function of soil organisms. However, the extent of such changes is difficult to generalize (beyond site-specific responses), as studies have yielded inconsistent results across ecosystems and disturbance severities.

- Links between plant diversity and soil biodiversity are ambiguous in US forests and rangelands. Thus, prioritizing conservation efforts to areas with high plant diversity may not protect soil organism diversity or function.

- Improved understanding of soil biodiversity, composition, function, and resilience is a pressing need to assist efforts to sustain and protect our forests and rangelands. Until recently, the use of traditional research techniques offered limited insight toward filling this knowledge gap. New and expanding molecular technologies now provide an unprecedented capability to address current and future ecological questions for the benefit of land stewardship.

\section{Key Information Needs}

\section{Science}

- Increased knowledge of soil biodiversity-currently, soil diversity is largely underdescribed. The groups with the most undescribed taxa are bacteria and archaea, but many groups, including fungi, nematodes, and insects, have numerous undescribed taxa.

- Distribution of soil organisms across ecosystems in North America-such information could help identify areas at risk from pathogens and categorize communities that perform specific ecosystem functions well (e.g., C storage, plant production, water infiltration).

- Continuation of taxonomic expertise, particularly for invertebrate taxa-fewer young scientists are being trained in these areas of expertise, and the field is at risk of becoming stagnant or even losing knowledge.

- More detailed information on how diverse soil communities contribute key ecosystem functions, including water filtration and storage, nutrient and $\mathrm{C}$ cycling, and wildlife habitat-combining emerging techniques like high-throughput sequencing and stable isotope probing (SIP) will deepen our understanding of these areas.

- Determine climate change impacts on soil communities-this is an ongoing area of research, and work needs to continue.

\section{Management Questions}

- How do soil organisms respond to management regimes such as thinning, prescribed fire, and grazing? This document provides an initial synthesis of some responses reported in the literature, but comprehensive synthesis reports and distilled fact sheets could further inform management decision-making processes.

- What invasive soil organisms are present and how do they spread? Some monitoring efforts are currently underway for invasive earthworms and flatworms, but there is a need for sustained, systematic monitoring.

- How can forest and rangeland management anticipate climate change and protect or enhance soil biodiversity to promote ecosystem resistance and resilience?

\section{Literature Cited}

Adamczyk JJ, Kruk A, Penczak T, Minter D (2012) Factors shaping communities of pyrophilous macrofungi in microhabitats destroyed by illegal campfires. Fungal Biol 116(9):995-1002

Allison SD, Martiny JB (2008) Resistance, resilience, and redundancy in microbial communities. Proc Natl Acad Sci 105(Suppl 1):11512-11519

Andriuzzi WS, Wall DH (2017) Responses of belowground communities to large aboveground herbivores: meta-analysis reveals biome-dependent patterns and critical research gaps. Glob Chang Biol 23(9):3857-3868

Arredondo JT, Johnson DA (1999) Root architecture and biomass allocation of three range grasses in response to nonuniform supply of nutrients and shoot defoliation. New Phytol 143(2):373-385

Bach EM, Williams RJ, Hargreaves SK et al (2018) Greatest soil microbial diversity found in micro-habitats. Soil Biol Biochem $118: 217-226$

Bailly J, Fraissinet-Tachet L, Verner M-C et al (2007) Soil eukaryotic functional diversity, a metatranscriptomic approach. ISME J 1(7):632-642

Bais HP, Fall R, Vivanco JM (2004) Biocontrol of Bacillus subtilis against infection of Arabidopsis roots by Pseudomonas syringae is facilitated by biofilm formation and surfactin production. Plant Physiol 134(1):307-319

Bardgett RD, van der Putten WH (2014) Belowground biodiversity and ecosystem functioning. Nature 515(7528):505-511

Barker JS, Simard SW, Jones MD, Durall DM (2013) Ectomycorrhizal fungal community assembly on regenerating Douglas-fir after wildfire and clearcut harvesting. Oecologia 172(4):1179-1189

Barrios E (2007) Soil biota, ecosystem services and land productivity. Ecol Econ 64(2):269-285 
Bastias BA, Anderson IC, Rangel-Castro JI et al (2009) Influence of repeated prescribed burning on incorporation of ${ }^{13} \mathrm{C}$ from cellulose by forest soil fungi as determined by RNA stable isotope probing. Soil Biol Biochem 41(3):467-472

Bastida F, Moreno JL, Nicolás C et al (2009) Soil metaproteomics: a review of an emerging environmental science-significance, methodology and perspectives. Eur J Soil Sci 60(6): 845-859

Bastow J (2012) Chapter 3.1: Succession, resource processing, and diversity in detrital food webs. In: Wall DH, Bardgett RD, Behan-Pelletier V et al (eds) Soil ecology and ecosystem services. Oxford: Oxford University Press, pp 117-135

Bates ST, Berg-Lyons D, Caporaso JG et al (2011) Examining the global distribution of dominant archaeal populations in soil. ISME J 5(5): 908-917

Battigelli JP, Spence JR, Langor DW, Berch SM (2004) Short-term impact of forest soil compaction and organic matter removal on soil mesofauna density and oribatid mite diversity. Can J For Res 34(5):1136-1149

Bellitürk K, Görres JH, Kunkle J, Melnichuk RDS (2015) Can commercial mulches be reservoirs of invasive earthworms? Promotion of ligninolytic enzyme activity and survival of Amynthas agrestis (Goto and Hatai, 1899). Appl Soil Ecol 87:27-31

Belnap J, Lange OL (2001) Structure and functioning of biological soil crusts: a synthesis. In: Belnap J, Lange OL (eds) Biological soil crusts: structure, function, and management, Ecological Studies 150. Springer, Berlin/Heidelberg, pp 471-479

Belnap J, Ludwig JA, Wilcox BP et al (2012) Introduced and invasive species in novel rangeland ecosystems: friends or foes? Rangel Ecol Manag 65(6):569-578

Blanc C, Sy M, Djigal D, Brauman A et al (2006) Nutrition on bacteria by bacterial-feeding nematodes and consequences on the structure of soil bacterial community. Eur J Soil Biol. 42(Suppl 1): $\mathrm{S} 70-\mathrm{S} 78$

Blankinship JC, Niklaus PA, Hungate BA (2011) A meta-analysis of responses of soil biota to global change. Oecologia 165(3):553-565

Bohlen PJ, Scheu S, Hale CM et al (2004) Nonnative invasive earthworms as agents of change in northern temperate forests. Front Ecol Environ 2(8):427-435

Bonkowski M, Villenave C, Griffiths B (2009) Rhizosphere fauna: the functional and structural diversity of intimate interactions of soil fauna with plant roots. Plant Soil 321(1-2):213-233

Bothe H, Słomka A (2017) Divergent biology of facultative heavy metal plants. J Plant Physiol 219:45-61

Brantley SL, Megonigal JP, Scatena FN et al (2011) Twelve testable hypotheses on the geobiology of weathering: hypotheses on geobiology of weathering. Geobiology 9(2): 140-165

Briones MJI, Garnett MH, Ineson P (2010) Soil biology and warming play a key role in the release of 'old C' from organic soils. Soil Biol Biochem 42(6):960-967

Briske DD (ed) (2017) Rangeland systems, Springer series on environmental management. Springer, Cham

Bronick CJ, Lal R (2005) Soil structure and management: a review. Geoderma 124(1):3-22

Brown SP, Callaham MA, Oliver AK, Jumpponen A (2013) Deep Ion Torrent sequencing identifies soil fungal community shifts after frequent prescribed fires in a southeastern US forest ecosystem. FEMS Microbiol Ecol 86(3):557-566

Burns RG, DeForest JL, Marxsen J et al (2013) Soil enzymes in a changing environment: current knowledge and future directions. Soil Biol Biochem 58:216-234

Busse MD, Shestak CJ, Hubbert KR, Knapp EE (2010) Soil physical properties regulate lethal heating during burning of woody residues. Soil Sci Soc Am J 74(3):947-955

Busse MD, Shestak CJ, Hubbert KR (2013) Soil heating during burning of forest slash piles and wood piles. Int J Wildland Fire 22(6):786
Butenko KO, Gongalsky KB, Korobushkin DI et al (2017) Forest fires alter the trophic structure of soil nematode communities. Soil Biol Biochem. 109(Suppl C):107-117

Cairney JWG, Bastias BA (2007) Influences of fire on forest soil fungal. Can J For Res 37(2):207-215

Cardenas E, Kranabetter JM, Hope G, et al (2015) Forest harvesting reduces the soil metagenomic potential for biomass decomposition. ISME J 9(11):2465-2476

Carini P,; Marsden PJ, Leff JW et al (2016) Relic DNA is abundant in soil and obscures estimates of soil microbial diversity. Nat Microbiol 2: 6242

Carpenter S, Trappe JM (1985) Phoenicoid fungi: a proposed term for fungi that fruit after heat treatment of substrates. Mycotaxon 103:203-206

Carpenter D, Hodson ME, Eggleton P, Kirk C (2007) Earthworm induced mineral weathering: preliminary results. Eur J Soil Biol 43:S176-S183

Certini G (2005) Effects of fire on properties of forest soils: a review. Oecologia 143(1):1-10

Chang C-H, Szlavecz K, Buyer JS (2016) Species-specific effects of earthworms on microbial communities and the fate of litterderived carbon. Soil Biol Biochem 100:129-139

Chang C-H, Szlavecz K, Buyer JS (2017) Amynthas agrestis invasion increases microbial biomass in Mid-Atlantic deciduous forests. Soil Biol Biochem 114:189-199

Chang C-H, Johnston MR, Görres JH et al (2018) Co-invasion of three Asian earthworms, Metaphire hilgendorfi, Amynthas agrestis and Amynthas tokioensis in the USA, Biol Invasions 20: $843-848$

Chen Y, Murrell JC (2010) When metagenomics meets stableisotope probing: progress and perspectives. Trends Microbiol 18(4):157-163

Cicconardi F, Borges PAV, Strasberg D et al (2017) MtDNA metagenomics reveals large-scale invasion of belowground arthropod communities by introduced species. Mol Ecol 26(12): 3104-3115

Coats VC, Pelletreau KN, Rumpho ME (2014) Amplicon pyrosequencing reveals the soil microbial diversity associated with invasive Japanese barberry (Berberis thunbergii DC.). Mol Ecol 23(6):1318-1332

Coleman DC, Callaham MA Jr, Crossley DA Jr (2018) Chapter 7: Soil biodiversity and linkages to soil processes. In: Coleman DC, Callaham MA Jr, Crossley DA Jr (eds) Fundamentals of soil ecology, 3rd edn. Academic, London, pp 233-253. https://www. sciencedirect.com/science/article/pii/B9780128052518000077 (January 22, 2018)

Connell JH (1978) Diversity in tropical rain forests and coral reefs. Science 199(4335):1302

Cowan AD, Smith JE, Fitzgerald SA (2016) Recovering lost ground: effects of soil burn intensity on nutrients and ectomycorrhiza communities of ponderosa pine seedlings. For Ecol Manag 378:160-172

Coyle DR, Nagendra UJ, Taylor MK et al (2017) Soil fauna responses to natural disturbances, invasive species, and global climate change: current state of the science and a call to action. Soil Biol Biochem 110:116-133

Craigg TL, Adams PW, Bennett KA (2015) Soil matters: improving forest landscape planning and management for diverse objectives with soils information and expertise. J For 113(3):343-353

Craven D, Thakur MP, Cameron EK et al (2017) The unseen invaders: introduced earthworms as drivers of change in plant communities in North American forests (a meta-analysis). Glob Chang Biol 23(3):1065-1074

Creer S, Deiner K, Frey S et al (2016) The ecologist's field guide to sequence-based identification of biodiversity. Methods Ecol Evol 7(9):1008-1018 
Crotty FV, Adl SM, Blackshaw RP, Murray PJ (2012) Protozoan pulses unveil their pivotal position within the soil food web. Microb Ecol 63(4):905-918

Crumsey JM, Le Moine JM, Vogel CS, Nadelhoffer KJ (2014) Historical patterns of exotic earthworm distributions inform contemporary associations with soil physical and chemical factors across a northern temperate forest. Soil Biol Biochem 68:503-514

Dávalos A, Simpson E, Nuzzo V, Blossey B (2015) Non-consumptive effects of native deer on introduced earthworm abundance. Ecosystems 18(6):1029-1042

De Vries FT, van Groenigen JW, Hoffland E, Bloem J (2011) Nitrogen losses from two grassland soils with different fungal biomass. Soil Biol Biochem 43:997-1005

Decaëns T, Jiménez JJ, Gioia C et al (2006) The values of soil animals for conservation biology. Eur J Soil Biol 42:S23-S38

DeGasperis BG, Motzkin G (2007) Windows of opportunity: historical and ecological controls on Berberis thunbergii invasions. Ecology 88(12):3115-3125

Deharveng L (2004) Recent advances in Collembola systematics. Pedobiologia 48(5-6):415-433

Dempsey MA, Fisk MC, Fahey TJ (2011) Earthworms increase the ratio of bacteria to fungi in northern hardwood forest soils, primarily by eliminating the organic horizon. Soil Biol Biochem 43(10):2135-2141

Dempsey MA, Fisk MC, Yavitt JB et al (2013) Exotic earthworms alter soil microbial community composition and function. Soil Biol Biochem 67:263-270

Dlott G, Maul JE, Buyer J, Yarwood S (2015) Microbial rRNA:rDNA gene ratios may be unexpectedly low due to extracellular DNA preservation in soils. J Microbiol Methods 115:112-120

Dobson A, Blossey B (2015) Earthworm invasion, white-tailed deer and seedling establishment in deciduous forests of north-eastern North America. J Ecol 103(1):153-164

Dumont MG, Murrell JC (2005) Stable isotope probing-linking microbial identity to function. Nat Rev Microbiol 3(6):499

Dumont MG, Pommerenke B, Casper P, Conrad R (2011) DNA-, rRNA- and mRNA-based stable isotope probing of aerobic methanotrophs in lake sediment: stable isotope probing of methanotrophs. Environ Microbiol 13(5):1153-1167

Eisenhauer N, Partsch S, Parkinson D, Scheu S (2007) Invasion of a deciduous forest by earthworms: changes in soil chemistry, microflora, microarthropods and vegetation. Soil Biol Biochem 39(5):1099-1110

Ekelund F, Saj S, Vestergård M et al (2009) The "soil microbial loop" is not always needed to explain protozoan stimulation of plants. Soil Biol Biochem 41(11):2336-2342

Ettema CH, Yeates GW (2003) Nested spatial biodiversity patterns of nematode genera in a New Zealand forest and pasture soil. Soil Biol Biochem 35(2):339-342

Fahey TJ, Yavitt JB, Sherman RE et al (2013) Earthworm effects on the incorporation of litter $\mathrm{C}$ and $\mathrm{N}$ into soil organic matter in a sugar maple forest. Ecol Appl 23(5):1185-1201

Faust K, Raes J (2012) Microbial interactions: from networks to models. Nat Rev Microbiol 10(8):538-550

Ferlian O, Cesarz S, Marhan S, Scheu S (2014) Carbon food resources of earthworms of different ecological groups as indicated by ${ }^{13} \mathrm{C}$ compound-specific stable isotope analysis. Soil Biol Biochem 77:22-30

Ferlian O, Klarner B, Langeneckert AE, Scheu S (2015) Trophic niche differentiation and utilisation of food resources in Collembolans based on complementary analyses of fatty acids and stable isotopes. Soil Biol Biochem 82:28-35

Fernández-Calviño D, Rousk J, Brookes PC, Bååth E (2011) Bacterial $\mathrm{pH}$-optima for growth track soil $\mathrm{pH}$, but are higher than expected at low pH. Soil Biol Biochem 43(7):1569-1575
Fetzer I, Johst K, Schäwe R et al (2015) The extent of functional redundancy changes as species' roles shift in different environments. Proc Natl Acad Sci 112(48):14888-14893

Ficetola GF, Pansu J, Bonin A et al (2015) Replication levels, false presences and the estimation of the presence/absence from eDNA metabarcoding data. Mol Ecol Resour 15(3):543-556

Fierer N, Jackson RB (2006) The diversity and biogeography of soil bacterial communities. Proc Natl Acad Sci 103(3):626-631

Fierer N, Strickland MS, Liptzin D et al (2009) Global patterns in belowground communities. Ecol Lett 12(11):1238-1249

Fisher MC, Henk DA, Briggs CJ et al (2012) Emerging fungal threats to animal, plant and ecosystem health. Nature 484(7393): 186-194

Fujimura KE, Smith JE, Horton TR et al (2005) Pezizalean mycorrhizas and sporocarps in ponderosa pine (Pinus ponderosa) after prescribed fires in eastern Oregon, USA. Mycorrhiza 15(2):79-86

Gall JE, Boyd RS, Rajakaruna N (2015) Transfer of heavy metals through terrestrial food webs: a review. Environ Monit Assess 187:201

Gao M, Taylor MK, Callaham MA (2017) Trophic dynamics in a simple experimental ecosystem: interactions among centipedes, Collembola and introduced earthworms. Soil Biol Biochem 115:66-72

García-Palacios P, Vandegehuchte ML, Shaw EA et al (2015) Are there links between responses of soil microbes and ecosystem functioning to elevated $\mathrm{CO}_{2}, \mathrm{~N}$ deposition and warming? A global perspective. Glob Chang Biol 21(4): 1590-1600

Gebremikael MT, Steel H, Buchan D et al (2016) Nematodes enhance plant growth and nutrient uptake under $\mathrm{C}$ and $\mathrm{N}$-rich conditions. Sci Rep 6: 32862

Geisen S (2016) The bacterial-fungal energy channel concept challenged by enormous functional versatility of soil protists. Soil Biol Biochem 102:22-25

Giller KE, Witter E, McGrath SP (2009) Heavy metals and soil microbes. Soil Biol Biochem 41(10):2031-2037

Glassman SI, Levine CR, DiRocco AM et al (2016) Ectomycorrhizal fungal spore bank recovery after a severe forest fire: some like it hot. ISME J 10(5): 1228-1239

Gorbunova AY, Korobushkin DI, Zaitsev AS, Gongalsky KB (2017) Forest fires increase variability of soil macrofauna communities along a macrogeographic gradient. Eur J Soil Biol 80:49-52

Graham EB, Wieder WR, Leff JW et al (2014) Do we need to understand microbial communities to predict ecosystem function? A comparison of statistical models of nitrogen cycling processes Soil Biol Biochem 68: 279-282

Grayston SJ, Rennenberg H (2006) Assessing effects of forest management on microbial community structure in a central European beech forest. Can J For Res 36(10):2595-2604

Greiner HG, Kashian DR, Tiegs SD (2012) Impacts of invasive Asian (Amynthas hilgendorfi) and European (Lumbricus rubellus) earthworms in a North American temperate deciduous forest. Biol Invasions 14(10):2017-2027

Griffiths BS, Philippot L (2013) Insights into the resistance and resilience of the soil microbial community. FEMS Microbiol Rev $37(2): 112-129$

Grigal DF (2000) Effects of extensive forest management on soil productivity. For Ecol Manag 138(1):167-185

Groffman PM, Bohlen PJ, Fisk MC, Fahey TJ (2004) Exotic earthworm invasion and microbial biomass in temperate forest soils. Ecosystems 7(1):45-54

Groffman PM, Fahey TJ, Fisk MC et al (2015) Earthworms increase soil microbial biomass carrying capacity and nitrogen retention in northern hardwood forests. Soil Biol Biochem 87:51-58 
Hale CM, Frelich LE, Reich PB, Pastor J (2005) Effects of european earthworm invasion on soil characteristics in Northern Hardwood forests of Minnesota, USA. Ecosystems 8(8):911-927

Hale CM, Frelich LE, Reich PB (2006) Changes in hardwood forest understory plant communities in response to European earthworm invasions. Ecology 87(7):1637-1649

Hartmann M, Howes CG, VanInsberghe D et al (2012) Significant and persistent impact of timber harvesting on soil microbial communities in northern coniferous forests. ISME J 6: 2199

Hawkes CV, Belnap J, D'Antonio C, Firestone MK (2006) Arbuscular mycorrhizal assemblages in native plant roots change in the presence of invasive exotic grasses. Plant Soil 281(1-2):369-380

Hebel CL, Smith JE, Cromack K (2009) Invasive plant species and soil microbial response to wildfire burn severity in the Cascade Range of Oregon. Appl Soil Ecol 42(2):150-159

Hendrix PF (ed) (1995) Earthworm ecology and biogeography in North America. CRC Press, Boca Raton

Hendrix PF, Callaham MA, Drake JM et al (2008) Pandora's box contained bait: the global problem of introduced earthworms. Annu Rev Ecol Evol Syst 39(1): 593-613

Hessburg PF, Churchill DJ, Larson AJ et al (2015) Restoring fireprone Inland Pacific landscapes: seven core principles. Landsc Ecol 30(10):1805-1835

Hinsinger P (2001) Bioavailability of soil inorganic P in the rhizosphere as affected by root-induced chemical changes: a review. Plant Soil 237(2):173-195

Högberg P, Johannisson C, Yarwood S et al (2011) Recovery of ectomycorrhiza after 'nitrogen saturation' of a conifer forest. New Phytol 189(2):515-525

Holden SR, Treseder KK (2013) A meta-analysis of soil microbial biomass responses to forest disturbances. Front Microbiol 4:163

Hungate BA, Mau RL, Schwartz E et al (2015) Quantitative microbial ecology through stable isotope probing. Appl Environ Microbiol 81(21):7570-7581

Huston MA (2014) Disturbance, productivity, and species diversity: empiricism vs. logic in ecological theory. Ecology 95(9):2382-2396

Hutchens E (2009) Microbial selectivity on mineral surfaces: possible implications for weathering processes. Fungal Biol Rev 23(4):115-121

Ingram LJ, Stahl PD, Schuman GE et al (2008) Grazing impacts on soil carbon and microbial communities in a mixed-grass ecosystem. Soil Sci Soc Am J 72(4): 939

Jansson JK, Neufeld JD, Moran MA, Gilbert JA (2012) Omics for understanding microbial functional dynamics. Environ Microbiol 14(1): $1-3$

Johansen JR (2001) Impacts of fire on biological soil crusts. In: Belnap J, Lange OL (eds) Biological soil crusts: structure, function, and management, Ecological Studies 150. Springer, Berlin/ Heidelberg, pp 385-397

Jones DL, Nguyen C, Finlay RD (2009) Carbon flow in the rhizosphere: carbon trading at the soil-root interface. Plant Soil 321(1-2):5-33

Jury WA, Gardner WR, Gardner WH (1991) Soil physics. Wiley, New York. 328 p

Kardol P, Wardle DA (2010) How understanding abovegroundbelowground linkages can assist restoration ecology. Trends Ecol Evol 25(11):670-679

Keeley JE (2009) Fire intensity, fire severity and burn severity: a brief review and suggested usage. Int J Wildland Fire 18(1):116

Keith AM, Brooker RW, Osler GHR et al (2009) Strong impacts of belowground tree inputs on soil nematode trophic composition. Soil Biol Biochem 41(6):1060-1065

Keith DM, Johnson EA, Valeo C (2010) Moisture cycles of the forest floor organic layer (F and $\mathrm{H}$ layers) during drying. Water Resour Res 46:7529
Kergunteuil A, Campos-Herrera R, Sánchez-Moreno S et al (2016) The abundance, diversity, and metabolic footprint of soil nematodes is highest in high elevation alpine grasslands. Front Ecol Evol 4:84

Kibblewhite MG, Ritz K, Swift MJ (2008) Soil health in agricultural systems. Philos Trans R Soc B Biol Sci 363:685-701

Kimura M, Jia Z-J, Nakayama N, Asakawa S (2008) Ecology of viruses in soils: past, present and future perspectives. Soil Sci Plant Nutr 54(1):1-32

Kind T, Wohlgemuth G, Lee DY et al (2009) FiehnLib: mass spectral and retention index libraries for metabolomics based on quadrupole and time-of-flight gas chromatography/mass spectrometry. Anal Chem 81(24):10038-10048

King JR, Warren RJ, Bradford MA (2013) Social insects dominate eastern US temperate hardwood forest macroinvertebrate communities in warmer regions. PLoS One 8(10):e75843

Kluber LA, Tinnesand KM, Caldwell BA et al (2010) Ectomycorrhizal mats alter forest soil biogeochemistry. Soil Biol Biochem 42(9):1607-1613

Koek MM, Muilwijk B, van der Werf MJ, Hankemeier T (2006) Microbial metabolomics with gas chromatography/mass spectrometry. Anal Chem 78(4):1272-1281

Kourtev PS, Huang WZ, Ehrenfeld JG (1999) Differences in earthworm densities and nitrogen dynamics in soils under exotic and native plant species. Biol Invasions 1(2-3):237-245

Kourtev PS, Ehrenfeld JG, Häggblom M (2002) Exotic plant species alter the microbial community structure and function in the soil. Ecology 83(11):3152-3166

Kurth F, Feldhahn L, Bönn M et al (2015) Large scale transcriptome analysis reveals interplay between development of forest trees and a beneficial mycorrhiza helper bacterium. BMC Genomics 16:658

Lambers H, Mougel C, Jaillard B, Hinsinger P (2009) Plant-microbesoil interactions in the rhizosphere: an evolutionary perspective. Plant Soil 321(1-2):83-115

Lennon JT, Jones SE (2011) Microbial seed banks: the ecological and evolutionary implications of dormancy. Nat Rev Microbiol 9(2):119-130

Lennon JT, Placella SA, Muscarella ME (2017) Relic DNA contributes minimally to estimates of microbial diversity. bioRxiv: 131284

Lensing JR, Wise DH (2007) Impact of changes in rainfall amounts predicted by climate-change models on decomposition in a deciduous forest. Appl Soil Ecol 35(3):523-534

Leung HTC, Maas KR, Wilhelm RC, Mohn WW (2016) Long-term effects of timber harvesting on hemicellulolytic microbial populations in coniferous forest soils. ISME J 10(2):363-375

Li L, Vogel J, He Z et al (2016) Association of soil aggregation with the distribution and quality of organic carbon in soil along an elevation gradient on Wuyi Mountain in China. PLoS One 11(3):e0150898

Ma JF, Ueno H, Ueno D et al (2003) Characterization of phytosiderophore secretion under Fe deficiency stress in Festuca rubra. Plant Soil 256(1):131-137

Ma Y, Filley TR, Johnston CT et al (2013) The combined controls of land use legacy and earthworm activity on soil organic matter chemistry and particle association during afforestation. Org Geochem 58:56-68

Malik AA, Thomson BC, Whiteley AS et al (2017) Bacterial physiological adaptations to contrasting edaphic conditions identified using landscape scale metagenomics. MBio. 8(4):e00799-e00717

Malmström A (2012) Life-history traits predict recovery patterns in Collembola species after fire: a 10 year study. Appl Soil Ecol 56(Suppl C):35-42

Maxfield PJ, Dildar N, Hornibrook ERC et al (2012) Stable isotope switching (SIS): a new stable isotope probing (SIP) approach to determine carbon flow in the soil food web and dynamics in organic matter pools. Rapid Commun Mass Spectrom 26(8):997-1004 
Menzel R, Ngosong C, Ruess L (2017) Isotopologue profiling enables insights into dietary routing and metabolism of trophic biomarker fatty acids. Chemoecology 27(3):101-114

Metzker ML (2010) Sequencing technologies-the next generation. Nat Rev Genet 11(1):31-46

Microbiology by numbers (2011) Nat Rev Microbiol 9(9):628

Miravete V, Roura-Pascual N, Dunn RR, Gómez C (2014) How many and which ant species are being accidentally moved around the world? Biol Lett 10:20140518

Myrold DD, Zeglin LH, Jansson JK (2014) The potential of metagenomic approaches for understanding soil microbial processes. Soil Sci Soc Am J 78(1):3

National Wildlife Coordinating Group [NWCG] (2003) Glossary of wildland fire terminology. https://www.nwcg.gov/glossary-ofwildland-fire-terminology. Accessed 8 Jan 2018

Nemec KT (2014) Tallgrass prairie ants: their species composition, ecological roles, and response to management. J Insect Conserv 18(4):509-521

Ngosong C, Gabriel E, Ruess L (2014) Collembola grazing on arbuscular mycorrhiza fungi modulates nutrient allocation in plants. Pedobiologia 57(3):171-179

Nielsen UN, Ayres E, Wall DH, Bardgett RD (2011) Soil biodiversity and carbon cycling: a review and synthesis of studies examining diversity-function relationships. Eur J Soil Sci 62(1):105-116

Nuzzo VA, Maerz JC, Blossey B (2009) Earthworm invasion as the driving force behind plant invasion and community change in northeastern North American forests. Conserv Biol 23(4):966-974

Oliver AK, Callaham MA, Jumpponen A (2015) Soil fungal communities respond compositionally to recurring frequent prescribed burning in a managed southeastern US forest ecosystem. For Ecol Manag 345:1-9

Orgiazzi A, Bardgett RD, Barrios E et al (eds) (2016) Global soil diversity atlas. Luxembourg: European Commission. https://doi. org/10.2788/2613

Overby ST, Gottfried GJ (2017) Microbial and nitrogen pool response to fuel treatments in pinyon-juniper woodlands of the southwestern USA. For Ecol Manag 406(Suppl C):138-146

Overby S, Hart S (2016) Short-term belowground responses to thinning and burning treatments in southwestern ponderosa pine forests of the USA. Forests 7(2):45

Overby ST, Owen SM, Hart SC et al (2015) Soil microbial community resilience with tree thinning in a 40-year-old experimental ponderosa pine forest. Appl Soil Ecol 93:1-10

Page-Dumroese D, Jurgensen M, Elliot W et al (2000) Soil quality standards and guidelines for forest sustainability in northwestern North America. For Ecol Manag 138(1):445-462

Park O, Kim J, Ryu C-M, Park C-S (2004) Colonization and population changes of a biocontrol agent, Paenibacillus polymyxa E681, in seeds and roots. Plant Pathol J 20(2):97-102

Petersen PM (1970) Danish fireplace fungi: an ecological investigation on fungi on burns. Dansk Botanisk Arkiv 27(3):1-97

Philippot L, Raaijmakers JM, Lemanceau P, van der Putten WH (2013a) Going back to the roots: the microbial ecology of the rhizosphere. Nat Rev Microbiol 11(11):789-799

Philippot L, Spor A, Hénault C et al (2013b) Loss in microbial diversity affects nitrogen cycling in soil. ISME J 7(8):1609-1619

Pimentel D (ed) (2014) Biological invasions: economic and environmental costs of alien plant, animal, and microbe species. CRC Press, Boca Raton. 463 p

Pold G, DeAngelis K (2013) Up against the wall: the effects of climate warming on soil microbial diversity and the potential for feedbacks to the carbon cycle. Diversity 5(2):409-425

Pollierer MM, Langel R, Scheu S, Maraun M (2009) Compartmentalization of the soil animal food web as indicated by dual analysis of stable isotope ratios $\left({ }^{15} \mathrm{~N} /{ }^{14} \mathrm{~N}\right.$ and $\left.{ }^{13} \mathrm{C} /{ }^{12} \mathrm{C}\right)$. Soil Biol Biochem 41(6):1221-1226

Ponder F, Fleming RL, Berch S et al (2012) Effects of organic matter removal, soil compaction and vegetation control on 10th year biomass and foliar nutrition: LTSP continent-wide comparisons. For Ecol Manag. 278(Suppl C):35-54

Powers RF (2006) Long-Term Soil Productivity: genesis of the concept and principles behind the program. Can J For Res 36(3):519-528

Powers RF, Scott DA, Sanchez FG et al (2005) The North American Long-Term Soil Productivity experiment: findings from the first decade of research. For Ecol Manag 220(1):31-50

Pringle A, Bever JD, Gardes M et al (2009) Mycorrhizal symbioses and plant invasions. Annu Rev Ecol Evol Syst 40(1):699-715

Pritchard SG, Taylor BN, Cooper ER et al (2014) Long-term dynamics of mycorrhizal root tips in a loblolly pine forest grown with free-air $\mathrm{CO}_{2}$ enrichment and soil $\mathrm{N}$ fertilization for 6 years. Glob Chang Biol 20(4):1313-1326

Quirk J, Beerling DJ, Banwart SA et al (2012) Evolution of trees and mycorrhizal fungi intensifies silicate mineral weathering. Biol Lett 8(6):1006-1011.

Raynaud X, Nunan N (2014) Spatial ecology of bacteria at the microscale in soil. PLoS One 9(1):e87217

Reazin C, Morris S, Smith JE et al (2016) Fires of differing intensities rapidly select distinct soil fungal communities in a northwest US ponderosa pine forest ecosystem. For Ecol Manag 377:118-127

Resner K, Yoo K, Hale C et al (2011) Elemental and mineralogical changes in soils due to bioturbation along an earthworm invasion chronosequence in northern Minnesota. Appl Geochem 26:S127-S131

Resner K, Yoo K, Sebestyen SD et al (2015) Invasive earthworms deplete key soil inorganic nutrients $(\mathrm{Ca}, \mathrm{Mg}, \mathrm{K}$, and $\mathrm{P})$ in a northern hardwood forest. Ecosystems 18(1):89-102

Robin A, Vansuyt G, Hinsinger P et al (2008) Iron dynamics in the rhizosphere: consequences for plant health and nutrition. Adv Agron 99:183-225

Ruess L, Schütz K, Migge-Kleian S (2007) Lipid composition of Collembola and their food resources in deciduous forest stands: implications for feeding strategies. Soil Biol Biochem 39(8): 1990-2000

Schneider K, Maraun M (2009) Top-down control of soil microarthropods: evidence from a laboratory experiment. Soil Biol Biochem 41(1): 170-175

Schneider T, Keiblinger KM, Schmid E et al (2012) Who is who in litter decomposition? Metaproteomics reveals major microbial players and their biogeochemical functions. ISME J 6:1749

Shade A, Peter H, Allison SD et al (2012) Fundamentals of microbial community resistance and resilience. Front Microbiol 3:417

Shestak CJ, Busse MD (2005) Compaction alters physical but not biological indices of soil health. Soil Sci Soc Am J 69(1):236-246

Sigler WV, Zeyer J (2004) Colony-forming analysis of bacterial community succession in deglaciated soils indicates pioneer stresstolerant opportunists. Microb Ecol 48(3):316-323

Singh BK, Bardgett RD, Smith P, Reay DS (2010) Microorganisms and climate change: terrestrial feedbacks and mitigation options. Nat Rev Microbiol 8(11):779-790

Six J, Elliott ET, Paustian K (2000) Soil macroaggregate turnover and microaggregate formation: a mechanism for $\mathrm{C}$ sequestration under no-tillage agriculture. Soil Biol Biochem 32(14):2099-2103

Sławska M, Bruckner A, Sławski M (2017) Edaphic Collembola assemblages of European temperate primeval forests gradually change along a forest-type gradient. Eur J Soil Biol 80:92-101

Smith DP, Peay KG (2014) Sequence depth, not PCR replication, improves ecological inference from next generation DNA sequencing. PLoS One 9(2):e90234 
Smith JE, McKay D, Niwa CG et al (2004) Short-term effects of seasonal prescribed burning on the ectomycorrhizal fungal community and fine root biomass in ponderosa pine stands in the Blue Mountains of Oregon. Can J For Res 34(12):2477-2491

Smith JE, McKay D, Brenner G et al (2005) Early impacts of forest restoration treatments on the ectomycorrhizal fungal community and fine root biomass in a mixed conifer forest: prescribed fire and EMF species richness. J Appl Ecol 42(3):526-535

Smith JE, Cowan AD, Fitzgerald SA (2016) Soil heating during the complete combustion of mega-logs and broadcast burning in central Oregon USA pumice soils. Int J Wildland Fire 25(11):1202

Smith JE, Kluber LA, Jennings TN (2017) Does the presence of large down wood at the time of a forest fire impact soil recovery? For Ecol Manag 391:52-62

Snyder BA, Callaham MA, Hendrix PF (2011) Spatial variability of an invasive earthworm (Amynthas agrestis) population and potential impacts on soil characteristics and millipedes in the Great Smoky Mountains National Park, USA. Biol Invasions 13(2):349-358

Southworth D, Donohue J, Frank JL, Gibson J (2011) Mechanical mastication and prescribed fire in conifer-hardwood chaparral: differing responses of ectomycorrhizae and truffles. Int J Wildland Fire 20(7):888

Stefanowicz AM, Stanek M, Woch MW (2016) High concentrations of heavy metals in beech forest understory plants growing on waste heaps left by $\mathrm{Zn}-\mathrm{Pb}$ ore mining. J Geochem Explor 169:157-162

Stephenson SL (2011) From morphological to molecular: studies of myxomycetes since the publication of the Martin and Alexopoulos (1969) monograph. Fungal Divers 50(1):21-34

Steven B, Kuske CR, Gallegos-Graves LV et al (2015) Climate change and physical disturbance manipulations result in distinct biological soil crust communities. Appl Environ Microbiol 81(21): 7448-7459

Szlávecz K, Csuzdi C (2007) Land use change affects earthworm communities in eastern Maryland, USA. Eur J Soil Biol 43:S79-S85

Szlavecz K, McCormick M, Xia L et al (2011) Ecosystem effects of nonnative earthworms in Mid-Atlantic deciduous forests. Biol Invasions 13(5):1165-1182

Taylor Grazing Act of 1934; Act of June 28, 1934; as amended June 26, 1936; 43 U.S.C. 315

Tedersoo L, Nara K (2010) General latitudinal gradient of biodiversity is reversed in ectomycorrhizal fungi. New Phytol 185(2):351-354

Trappe MJ, Cromack K Jr, Trappe JM et al (2009) Interactions among prescribed fire, soil attributes, and mycorrhizal community structure at Crater Lake National Park, Oregon, USA. Fire Ecol $5(2): 30-50$

Treseder KK (2004) A meta-analysis of mycorrhizal responses to nitrogen, phosphorus, and atmospheric $\mathrm{CO}_{2}$ in field studies. New Phytol 164(2):347-355

Treseder KK, Marusenko Y, Romero-Olivares AL, Maltz MR (2016) Experimental warming alters potential function of the fungal community in boreal forest. Glob Chang Biol 22(10):3395-3404

Turbé A, De Toni A, Benito P et al (2010) Soil biodiversity: functions, threats and tools for policy makers. Bioemco 00560420

Tyler G, Påhlsson A-MB, Bengtsson GE et al (1989) Heavy-metal ecology of terrestrial plants, microorganisms and invertebrates. Water Air Soil Pollut 47(3):189-215

Ulyshen MD, Wagner TL, Mulrooney JE (2014) Contrasting effects of insect exclusion on wood loss in a temperate forest. Ecosphere 5(4): $1-15$

Urbanová M, Šnajdr J, Baldrian P (2015) Composition of fungal and bacterial communities in forest litter and soil is largely determined by dominant trees. Soil Biol Biochem 84:53-64

Uroz S, Calvaruso C, Turpault M-P, Frey-Klett P (2009) Mineral weathering by bacteria: ecology, actors and mechanisms. Trends Microbiol 17(8):378-387
Uroz S, Ioannidis P, Lengelle J et al (2013) Functional assays and metagenomic analyses reveals differences between the microbial communities inhabiting the soil horizons of a Norway spruce plantation. PLoS One 8(2):e55929

Uroz S, Buée M, Deveau A et al (2016) Ecology of the forest microbiome: highlights of temperate and boreal ecosystems. Soil Biol Biochem 103:471-488

Walker AP, Zaehle S, Medlyn BE et al (2015) Predicting long-term carbon sequestration in response to $\mathrm{CO}_{2}$ enrichment: how and why do current ecosystem models differ? Glob Biogeochem Cycles. 29(4):2014GB004995

Wall DH, Bradford MA, St. John MG et al (2008) Global decomposition experiment shows soil animal impacts on decomposition are climate-dependent. Glob Chang Biol 14(11):2661-2677

Wall DH, Bardgett RD, Behan-Pelletier V et al (eds) (2012) Soil ecology and ecosystem services. Oxford: Oxford University Press. 464 p

Wall DH, Nielsen UN, Six J (2015) Soil biodiversity and human health. Nature 528(7580):69-76

Wang K-H, McSorley R, Bohlen P, Gathumbi SM (2006) Cattle grazing increases microbial biomass and alters soil nematode communities in subtropical pastures. Soil Biol Biochem 38(7):1956-1965

Warcup JH (1990) Occurrence of ectomycorrhizal and saprophytic discomycetes after a wild fire in a eucalypt forest. Mycol Res 94(8):1065-1069

Warren S (1995) Chapter 11: Ecological role of microphytic soil crusts in arid environments. In: Allsopp A, Colwell RR, Hawksworth DL (eds) Microbial diversity and ecosystem function. CAB International, Wallingford, pp 199-209

Warren SD, Eldridge DJ (2001) Chapter 10: Biological soil crusts and livestock in arid ecosystems: are they compatible? In: Belnap J, Lange OL (eds) Biological soil crusts: structure, function, and management. Springer, Berlin/Heidelberg, pp 401-415

Warren SD, St. Clair LL, Leavitt SD (2017) Aerobiology and passive restoration of biological soil crusts. Biogeosci Discuss. https://doi. org/10.5194/bg-2017-430

Weber B, Burkhard Büdel B, Belnap J (eds) (2016) Biological soil crusts: an organizing principle in drylands. Springer, Cham

Wicklow DT (1975) Fire as an environmental cue initiating ascomycete development in a tallgrass prairie. Mycologia 67(4):852-862

Wilcove DS, Rothstein D, Dubow J et al (1998) Quantifying threats to imperiled species in the United States. Bioscience 48(8):607-615

Wilhelm RC, Cardenas E, Leung H et al (2017a) A metagenomic survey of forest soil microbial communities more than a decade after timber harvesting. Sci Data 4:170092

Wilhelm RC, Cardenas E, Maas KR et al (2017b) Biogeography and organic matter removal shape long-term effects of timber harvesting on forest soil microbial communities. ISME J 11(11):2552

Williamson KE, Fuhrmann JJ, Wommack KE, Radosevich M (2017) Viruses in soil ecosystems: an unknown quantity within an unexplored territory. Ann Rev Virol 4(1):201-219

Wilshire HG (1983) The impact of vehicles on desert soil stabilizers. In: Webb RH, Wilshire HG (eds) Environmental effects of offroad vehicles: impacts and management in arid regions. Springer, New York, pp 31-50

Yarwood SA, Högberg MN (2017) Soil bacteria and archaea change rapidly in the first century of Fennoscandian boreal forest development. Soil Biol Biochem 114:160-167

Yavitt JB, Fahey TJ, Sherman RE, Groffman PM (2015) Lumbricid earthworm effects on incorporation of root and leaf litter into aggregates in a forest soil, New York State. Biogeochemistry 125(2):261-273

Young IM, Crawford JW (2004) Interactions and self-organization in the soil-microbe complex. Science 304(5677):1634-1637 
Youssef NH, Couger MB, McCully AL et al (2015) Assessing the global phylum level diversity within the bacterial domain: a review. J Adv Res 6(3):269-282

Zhang W, Parker KM, Luo Y et al (2005) Soil microbial responses to experimental warming and clipping in a tallgrass prairie. Glob Chang Biol 11(2):266-277
Zhang X, Song C, Mao R et al (2015) Comparing differences in early-stage decay of macrophyte shoots between in the air and on the sediment surface in a temperate freshwater marsh. Ecol Eng 81:14-18

Open Access This chapter is licensed under the terms of the Creative Commons Attribution 4.0 International License (http://creativecommons. org/licenses/by/4.0/), which permits use, sharing, adaptation, distribution and reproduction in any medium or format, as long as you give appropriate credit to the original author(s) and the source, provide a link to the Creative Commons license and indicate if changes were made.

The images or other third party material in this chapter are included in the chapter's Creative Commons license, unless indicated otherwise in a credit line to the material. If material is not included in the chapter's Creative Commons license and your intended use is not permitted by statutory regulation or exceeds the permitted use, you will need to obtain permission directly from the copyright holder. 